\title{
Patients' and Health Care Professionals' Perceptions of Blood Transfusion: A Systematic Review
}

Authors: Brittannia Abdul-Aziz ${ }^{1}$; Fabiana Lorencatto ${ }^{1}$; Simon J. Stanworth ${ }^{2}$; Jill J. Francis $^{1}$

${ }^{1}$ Centre for Health Services Research, School of Health Sciences, City, University of London

${ }^{2}$ NHS Blood and Transplant/ Oxford University Hospitals NHS Foundation Trust, John Radcliffe Hospital, Oxford, UK, Oxford Clinical Research in Transfusion Medicine, University of Oxford, UK

Corresponding author: Brittannia Abdul-Aziz, School of Health Sciences, City, University of London, Northampton Square, London EC1V OHB

02070405807 Brittannia.Abdul-Aziz.1@city.ac.uk

Reprint requests: Brittannia Abdul-Aziz, School of Health Sciences, City, University of London, Northampton Square, London EC1V OHB

Brittannia.Abdul-Aziz.1@city.ac.uk

Source of funding: Doctoral Research Studentship, City, University of London

Conflict of interest: The authors declare that they have no conflicts of interest relevant to the manuscript submitted to TRANSFUSION

Word count: 3843

Running head: Perceptions of Blood Transfusion

This is the author manuscript accepted for publication and has undergone full peer review but has not been through the copyediting, typesetting, pagination and proofreading process, which may lead to differences between this version and the Version of record. Please cite this article as doi:10.1111/ trf.14404. 


\begin{abstract}
Background

Blood transfusions are frequently prescribed for acute and chronic conditions; however, the extent to which patients' and healthcare professionals' (HCPs') perceptions of transfusion have been investigated is unclear. Patients' treatment perceptions influence how patients cope with illnesses or symptoms. HCPs' perceptions may influence treatment decision-making.
\end{abstract}

\title{
Study design and methods
}

A systematic review of studies post-1984 reporting adult patients' and HCPs' perceptions of blood transfusion. Seven databases were searched using a three-domain search strategy capturing synonyms relating to: 1) blood transfusion; 2) perceptions; 3) participant group (patients or HCPs). Study and sample characteristics were extracted and narratively summarized. Reported perceptions were extracted and synthesized using inductive qualitative methods to identify key themes.

\section{Results}

Thirty-two studies were included: 14 investigated patients' perceptions, 18 HCPs' perceptions. Surgical patients were the highest represented patient group. HCPs were from a wide range of professions. Transfusions were perceived by patients and HCPs as being of low-to-moderate risk. Risk and negative emotions were perceived to influence preference for alternatives. Five themes emerged from the synthesis, classified as Safety/risk, Negative emotions, Alternatives (e.g., autologous, monitoring), Health benefits and Decision making. 'Safety/risk' and 'Negative emotions' were most frequently investigated over time, yet periods of research inactivity are apparent.

\section{Conclusions}

The literature has identified themes on how transfusions are perceived by patients and HCPs, which overlap with recognized discussion points for transfusion specialists. These themes may help healthcare professionals when educating patients about transfusion or consenting patients. Theorybased qualitative methods may add an important dimension to this work.

Keywords: Blood transfusion, treatment perceptions, beliefs, patient's perspective, healthcare professional-patient decision making.

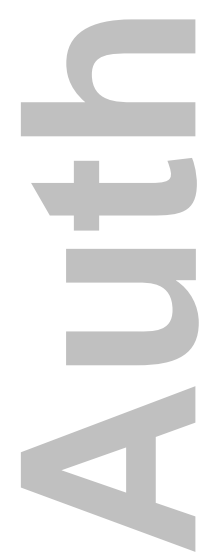




\section{Introduction}

The last decade has seen a marked increase in the numbers of randomized trials of the use of red cell transfusions and platelets, which has been reflected in updated guidance documents, such as

North American AABB red cell guidelines, informed by an updated Cochrane systematic review ${ }^{1}$. In turn, transfusion healthcare professionals (HCPs) have now focused more on the need to understand strategies that best support implementation of evidence based recommendations, alongside

strategies of enabling greater patient involvement in consent to transfusion, safe administration and appropriate use of blood.

In the UK, The National Institute for Health and Care Excellence (NICE) guidelines recommended provision of patient information with an objective to consider patients' experiences and preferences for information on blood transfusion ${ }^{2}$. A better understanding of patients' and HCPs' perceptions about blood transfusion could help to ensure that patients receive the information they require about blood transfusions, with equal consideration paid to the views of the HCPs. Likewise, Patient Blood Management (PBM) advocates patients being involved in decisions made about their transfusions ${ }^{3}$. However, this may not always be the case, indicated by literature reporting that transfusions may be refused by patients due to concerns about transfusion related risks and a lack of understanding by patients of the benefits and risks involved ${ }^{4}$. Exploring perceptions of transfusion may identify perceptions important to cover in transfusion consultations, whilst considering the broad range of patients receiving transfusions for both acute and chronic healthcare needs.

Perceptions may vary between patient groups which differ in terms of timing and frequency of transfusions, with transfusions being prescribed as a treatment in itself or as an adjunct to other treatments, such as chemotherapy or surgical procedures. Compared to patients receiving transfusions in emergency settings, where the transfusion may be given once, hematology patients often receive repeated transfusions and will thus be able to form perceptions before, during and after the transfusion. Perceptions may vary according to type of blood component being transfused

ScholarOne, 375 Greenbrier Drive, Charlottesville, VA, 229011 (434) 964-4100

This article is protected by copyright. All rights reserved. 
as the usage and risk profile of blood components vary, with platelets, for example, having the highest transfusion transmitted disease risk potential ${ }^{5}$. Different health professional groups may perceive transfusion differently from patients and between HCPs, with HCPs' views of transfusion

likely to be informed by their knowledge of the relevant clinical evidence and their own clinical experience, as has been demonstrated in respect of other treatments ${ }^{6} . \mathrm{HCPs}^{\prime}$ perceptions and knowledge naturally influence clinical decision-making, in which patients may be partly involved ${ }^{7}$.

It has been argued that investigating perceptions using recognized theories is important as theory offers a systematic way of understanding events or situations ${ }^{8}$. Blood transfusion is a type of treatment and the investigation of perceptions of transfusion may thus be informed by existing behavioral and psychological theoretical literature of treatment perceptions ${ }^{9,10}$. This literature reports that patients' perceptions, such as thoughts about how an illness could be curable or controlled through treatment, or emotional representations, such as fears or concerns ${ }^{9}$, influence coping strategies that patients select when choosing how to respond to their illnesses or symptoms ${ }^{9}$. If transfusions are perceived by patients as beneficial to improve their health, transfusions may be willingly accepted by patients to manage their health condition, potentially reducing more general illness concerns.

The treatment perceptions literature can be applied to transfusions, of importance due to the varied use of transfusions and the different options for patient groups to be involved (i.e. in the decision making). The extent to which perceptions of blood transfusion have been investigated in a theorybased manner is unclear. No existing systematic review of patients' and HCPs' perceptions of blood transfusion was identified from a prior search of systematic reviews of this topic (Appendix A: Systematic review search strategies).

This review aimed to synthesize findings reported in the healthcare literature regarding perceptions of blood transfusion, using a qualitative approach to identify emergent themes that describe patients' and HCPs' perceptions and to consider how the themes may inter-relate. 
Specific objectives were:

- To describe the designs and characteristics of studies used to investigate patients' and HCPs' blood transfusion perceptions

- To describe the patients and HCPs whose perceptions have been investigated, the timepoint in the transfusion process when patients' perceptions were investigated and whether different perceptions are held about different blood components

- To identify the extent to which existing theories of behavior have been cited and applied in studies

- To identify and thematically synthesize the content of blood transfusion perceptions reported for patients and HCPs

- To report how emergent themes were distributed per period of study publication.

\section{Methods}

\section{Study selection criteria}

Empirical studies were eligible for inclusion if they met the study inclusion criteria listed in Table 1. Patients participating in included studies were either transfusion recipients or were being prepared for a transfusion (i.e. patients donating blood for pre-operative autologous donation (PAD). HCPs were required to be treating adult transfusion patients.

\section{[INSERT TABLE 1]}

Perceptions of blood transfusion practice, such as satisfaction with the service, recall of informed consent, training or policy fell outside the scope of the review. No limiters were applied to geographical region. The publication date of studies was from 1984 onwards; 1984 marking the date of a potential shift in perceptions of blood transfusion after the link between blood transfusion and AIDS transmission was announced ${ }^{11}$. 


\section{Identification and selection of studies}

\section{(1)}

Searches were run initially in February 2014 and updated in November 2015. The following

databases were searched: Cochrane Central Register of Controlled Trials, the Cochrane Database of

Systematic Reviews, Database of Abstracts of Reviews of Effects, Ovid MEDLINE, EMBASE, PsycINFO and PSYARTICLES.

Search terms related to three domains: 1) blood transfusion (e.g. red cell transfusion); 2)

perceptions (e.g. belief or attitude); and 3) participant group (patients or HCPs, e.g. clinician). The search was applied to the studies' title and abstract fields.

\section{Study screening}

Studies were screened for inclusion by one reviewer (BA) at the title and abstract level, and subsequently at the full text level, against six inclusion criteria that were tested for reliability (Table 1). Review team members ( $F L+J F)$ independently assessed $1 \%$ ( $n=27$ studies) of randomly selected titles and abstracts excluded by BA to evaluate the validity of the screening decisions.

\section{Data extraction and synthesis}

In total, 25 data elements were extracted (data extraction form available on request).

Reliability analysis was performed on: 1) presence / absence of theory; and 2) reported perceptions. A colleague (AP) with experience in identifying theory, independently assessed the presence or absence of theory for $10 \%$ of randomly selected studies. For the reported perceptions, data related to perceptions of blood transfusion meeting the inclusion criteria were extracted. Such data points consisted of excerpts of both raw data (i.e. participant quotes and/or quantitative findings) and/or text reporting results as interpreted by study authors. A second reviewer $(\mathrm{FL})$ independently extracted the perceptions from $10 \%$ of a randomly selected sub-sample of studies. 


\section{Quality assessment of included studies}

Qusti

Quality was assessed for descriptive purposes rather than to inform study inclusion/exclusion.

Studies were appraised for quality by BA using validated quality assessment checklists ${ }^{12}$. Scores

produced using the checklists were reported as percentages (of quality criteria met) to enable comparison between studies.

\section{Data analysis}

Extracted data were tabulated for analysis and reported using narrative summary for all extracted data other than the reported perceptions ${ }^{13}$. A four-stage inductive qualitative synthesis ${ }^{14}$ was conducted to synthesize and interpret reported perceptions. First, one researcher (BA) reviewed and classified the extracted perceptions into subthemes using in vivo coding, where actual phrases from the excerpts were retained and used to name the subthemes ${ }^{15}$. Second, BA organized the subthemes into thematic groups using techniques from thematic analysis; searching for themes, by considering inter-relationships between subthemes ${ }^{16}$. The themes, subthemes and perceptions contained within them were discussed with review team members $(F L+J F)$ to reach consensus on a refined set of themes (synthesis stage 3$)^{17}$. BA then investigated intersections between the themes by reviewing the data to identify subthemes that intersected, whereby the subtheme could be allocated to more than one theme (synthesis stage 4).

\section{Results}

The search returned 2,696 unique results and two $0^{18,19}$ additional studies were identified from a systematic review identified in the search ${ }^{20} .100 \%$ agreement on screening decisions was reached. As displayed in Figure 1, 32 studies were included in the systematic review.

\section{[INSERT Fig. 1]}




\section{Study characteristics}

Studies were conducted between 1990 and 2015. Fourteen studies investigated patients'

perceptions $^{19,21-33}$ and eighteen studies investigated HCPs' perceptions of blood transfusion ${ }^{18,34-50}$

(Table 2). Three studies included patients and HCPs, however, only the data from one sample group was extracted (patients ${ }^{22,26}$ and $\mathrm{HCPs}^{36}$ ); meeting the scope of this review.

[INSERT TABLE 2]

The majority of studies were conducted in the $\mathrm{UK}^{22,25,26,30,31,38,40,45-47,50}$, were conducted at more than one health facility ${ }^{18,19,22,23,27,28,34,35,37-42,44-47,49,50}$, and in secondary healthcare settings s, $22-30,32-40,42-^{-}$ $44,47,49$.

\section{Patients and HCPs participating in included studies}

In total 1,558 patients participated in the included studies ( $48 \%$ male, aged between 18-95 years).

Patients were classified for this review as either transfusion recipients ${ }^{22-25,31-33}$ or patients being prepared for a transfusion ${ }^{21,26-29}$. Two studies included both patient groups ${ }^{19,30}$. Patients were broadly classified as: 1) receiving transfusions in the context of surgery only ${ }^{19,26-30}$;2) mixed groups of transfusion recipients participating in the same study $y^{21-25,33}$; 3) patients receiving regular transfusions every two to four weeks ${ }^{31}$; or 4) patients receiving transfusions for anemia ${ }^{32}$.

In total, 2,678 HCPs participated in the included studies. Eleven studies investigated a mix of HCP professions ${ }^{18,34-38,42,43,45,46,49}$, whilst seven studies assessed one HCP specialty or seniority (i.e. physicians / consultants ${ }^{39-41}$ surgeons $^{47}, \mathrm{GPs}:{ }^{48,50}$ and hospital managers or representatives) ${ }^{44}$. Most HCPs were male $\left(59 \%\right.$ reported for $n=7$ studies ${ }^{36,37,39,40,42,43,46}$ ) with between 1 and 25 years of reported clinical experience $e^{36,40,42}$. 


\section{Research designs and assessment approaches}

Cross-sectional designs were most common ${ }^{18,21-27,29,30,35-37,42,43,46,48,49}$ (Table 2). Materials were

published in reports of nine studies ${ }^{18,21,25,26,31,32,39,40,47}$ and additional materials were received from six

study authors ${ }^{19,23,28,35,37,38}$ of 24 who were contacted.

\section{Quality appraisal of included studies}

Overall the quality of the set of included papers was moderate to high. Quality appraisal ratings ranged from $45-100 \%$. Nine studies ${ }^{18,27,29-32,39,40,49}$ scored above $90 \%$, with $90 \%$ considered by review team members (BA+FL+JF) as the threshold indicating a high-quality study. Studies detailing steps taken to analyze and verify the data received, for example, high quality assessment scores $>90 \%{ }^{18,27,29,30,32,39,40,49}$. Studies where explanation was not provided of how the participants were selected, to ensure less biased responses, received lower scores $(<65 \%)^{24,26,41,47,48}$.

\section{Time points patients' perceptions assessed}

Two studies reported the time point at which the perceptions of patients who had received a transfusion were assessed, either within 48 hours of the transfusion ${ }^{22}$ or 'about 24 hours after the transfusion ${ }^{32}$

\section{Blood components investigated}

The majority of studies $(n=19)$ did not report which blood component was being investigated ${ }^{18,21-26,30-}$ $33,35,36,38,41-43,48,50$. Perceptions of red blood cell transfusion were investigated in three studies, either in isolation ${ }^{49}$ or compared with the alternative of 'monitoring' (i.e. 'managing a patient with borderline haemoglobin by watching and waiting instead of transfusing red cells' $)^{39,40}$. One study assessed HCPs' perceptions of transfusion of fresh frozen plasma (FFP) ${ }^{37}$.

\section{Citation of theory}

Reliability analysis of the presence or absence of theory reached $100 \%$ agreement between two reviewers. Eleven theories were identified across 11 studies (see Appendix B for all theories). Three 
studies cited multiple theories ${ }^{28,45,46}$ and in eight papers theory was cited in the introduction and discussion as well as being applied in the methods to inform the design of the study or study materials ${ }^{18,26,28,39,40,43,45,49}$. Six theories (Theories 2-7, Appendix B) consist of predominantly riskrelated constructs.

\section{Perceptions of blood transfusion}

Reliability of the extracted perceptions fell between $83 \%$ and $100 \%$, with disagreements discussed until $100 \%$ agreement was reached for each study.

Inductive qualitative synthesis

In total, 79 data points (excerpts of data containing the reported perceptions) were extracted across the 32 studies. As the data points often contained more than one reported perception, perceptions were classified by BA into 195 subthemes, arranged into 13 initial themes. The themes and subthemes were iteratively consolidated into five over-arching themes of perceptions of blood transfusion containing 23 subthemes (Appendix C). The final five themes can be considered as either: 1) cognitive ('Safety/risk', 'Alternatives', 'Health benefits'), 2) emotional ('Negative emotions'), or 3) behavioral ('Decision making'). Cognitive and emotional themes contain patients' and HCPs' perceptions reported as either thoughts or emotions experienced or hypothetically considered in relation to transfusion. For the 'Decision making' theme, the content represents perceptions that may result in behaviors that are observable in the clinical setting. Figure 3 displays the distribution of themes for each five-year period of publication. This shows that the themes

'Safety/Risk' and 'Negative emotions' have been frequently and increasingly investigated, while

'Health Benefits' and 'Decision making' received moderate research interest. Research relating to theme of 'Alternatives' reduced post 2005 and increased again in 2011 to 2015.

\section{Summary of themes}

Safety/risk: Patients and HCPs reported a low perceived risk of contracting an illness from contaminated blood ${ }^{19,29,44,46}$ with one study reporting decreases over a 12 year time period in a 
cohort of GPs' and their perceptions of blood transfusion risk ${ }^{41}$. Blood transfusion was ranked as having low / intermediate risk in comparison to other hazards (e.g. skiing, alcohol, nuclear reactors) ${ }^{43,45}$ and treatments (e.g. surgery or anaesthetic) ${ }^{30,35}$. Some patients reported risks associated with transfusions as being somewhat acceptable and unavoidable ${ }^{33}$. Some physicians reported confidence in the safety of blood, ${ }^{18}$ whereas others acknowledged potential danger associated with transfusion, such as the possibility of errors ${ }^{38}$ or transfusion-related acute lung injury ${ }^{37}$

Negative emotions: Many factors, such as disease or infection risk, ${ }^{19,32}$ adverse events, ${ }^{36,38}$ or general apprehension about receiving a transfusion ${ }^{23}$ were evident in reported concern or worry in patients and HCPs. Some physicians reported that they would be concerned if new viral / bacterial threats emerged, and therefore would reduce their level of blood product use ${ }^{18}$. Some patients did not report concerns about receiving transfusions ${ }^{19}$. Some HCPs reported concerns about watching and waiting instead of transfusing (i.e. in situations where a patient may become symptomatic) ${ }^{39,40}$.

Alternatives: Some surgical patients, surgeons, GPs and anesthetists reported preferring alternatives to reduce perceived risk associated with transfusion ${ }^{19,27,45,46}$. Willingness to pay for autologous transfusion (PAD) was also high for patients reporting dread of receiving an allogeneic transfusion $^{28,29}$. HCPs' motivations to consider alternatives for their patients were mixed, and influenced by evidence, technique complexity, patient demand, the patient's condition and perceptions of free and safe blood supplies ${ }^{34,39,40,44,47}$.

Health benefits: Patients tended to perceive transfusions as beneficial, understanding why the transfusion was necessary ${ }^{22,25}$, with benefit outweighing risk ${ }^{33}$. However, while some HCPs perceived transfusion to be beneficial ${ }^{43}$, others reported that not transfusing, and instead monitoring the patient's condition, may reduce transfusion risks ${ }^{39,40}$. Some hospice and hospital inpatients also found it difficult to perceive the benefit of the transfusion ${ }^{31}$, in some cases due to ill health associated with their medical conditions ${ }^{33}$. 
Decision making: HCPs reported making transfusion decisions on a case-by-case basis ${ }^{39,40,42}$, with a shift from blood being considered as 'good for everybody' 34 and decisions being to a lesser extent influenced by cost, the patient's age or the availability of blood ${ }^{42,49}$. For HCPs, acute or risk of

bleeding, functional deterioration and anemia (from chemo-and/or radiotherapy) were reasons for transfusions, and low hemoglobin levels and pallor increased the likelihood of deciding to

transfuse ${ }^{35,37,42}$. Some patients surveyed before and after transfusion counselling were less likely to report post counselling that doctors relied too much on transfusion ${ }^{26}$. Reasons for transfusion were reported by patients as generalized weakness, trauma and surgery ${ }^{22,23}$; with patients reporting that physicians often made the transfusion decisions ${ }^{32}$. Some patients in a low-income country would not consent to transfusion due to infection risk ${ }^{24}$.

Intersections between themes

Intersections between the themes were proposed (synthesis stage 4; Appendix D) and represented in a conceptual model (Figure 2) to portray the intersection between the themes that are either cognitive or emotional, with the behavioral 'Decision making' theme positioned to the right of the model. The model's central arrow portrays a relationship, based on the findings of the synthesis, between the cognitive or emotional themes, which are proposed to influence actions that patients and HCPs perform in clinical settings subsequent to 'Decision making' (i.e. providing consent to be transfused or prescribing a transfusion).

\section{[INSERT Fig 2.]}

\section{[INSERT Fig 3.]}

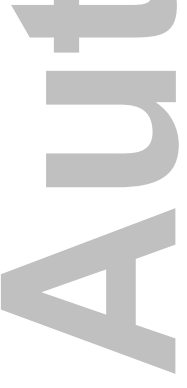




\section{Discussion}

Key findings

This systematic review identified 32 studies reporting adult patients' and HCPs' perceptions of blood transfusion. Most studies were conducted in the UK, were cross-sectional and investigated the perceptions of patients after transfusion or of patients receiving or being prepared for transfusions in relation to surgery. Studies involving HCPs tended to include HCPs from mixed professions in secondary healthcare settings. Theories including risk constructs were most frequently cited in this literature, with most studies citing or applying one single theory. Studies included in the review were considered to be of moderate to high quality.

The synthesis of the reported perceptions highlighted that patients and HCPs view transfusion with low to moderate risk, but that some perceptions of transfusion-associated risk, or negative emotions, were associated with the use or consideration of transfusion alternatives. Some patients perceived benefit from transfusion ${ }^{22,25}$, however, other patients found the benefit difficult to discern due to the impact of their illness ${ }^{31,33}$. It was also reported that HCPs led the decision making about transfusion $^{32}$.

\section{Comparison of themes to other literature}

The findings were synthesized into four cognitive or emotional themes ('Safety / risk,' 'Negative emotions', 'Alternatives' and 'Health benefits') and one behavioral theme: 'Decision making'. 'Safety

/ risk' and 'Negative emotions' were the most highly researched themes, potentially driven by interest towards understanding perceptions of blood transfusion risk following historical threats to global blood supplies. The cognitive or emotional themes broadly correspond to existing subscales of treatment perceptions from the Beliefs about Medicines Questionnaire (BMQ) $)^{10}$ (summary available on request). Based on this convergence, if faced with a health threat (illness or symptoms, as proposed in the Common-Sense Self-Regulation Model (CS-SRM $)^{9}$ ), and a transfusion is proposed, patients may form and deal with perceptions that are familiar to them, from their experiences with 
other treatments. Patients may utilize the range of coping strategies proposed in the CS-SRM, such as positive appraisal (appraising an encounter more positively to reduce negative emotions) ${ }^{51}$. For instance, patients having transfusions in emergency settings may hold negative emotions about transfusion, but positively appraise it as a life-saving intervention.

Implications for practice

The findings of this review can be used by HCPs when discussing transfusion decisions with their patients in consultations, with the identified themes converging with UK guidance on issues to be discussed with transfusion patients, such as the risks, benefits of transfusion and possible alternatives ${ }^{52}$. Greater emphasis could be given to address patient concerns about having a transfusion, as some patient concerns related to disease or infection risk from blood transfusion ${ }^{19,32}$ were elevated in comparison to reported HCP concerns, which were more linked to the possibility of adverse events, such as allergic reactions ${ }^{36}$. These findings, however, may not be wholly applicable to low- and middle-income countries, which may have varying resources and levels of risk exposures.

This review identified that some patients in a low-income country held concerns about transfusion because of perceived risks ${ }^{24}$, indicating that greater discussion of these themes would be beneficial.

\section{Implications for future research}

The overall findings of the review highlight several research gaps, where perceptions could be explored further, taking into account key settings where transfusions are frequently prescribed. Transfusions are reported to be highly used in medical contexts in the UK, such as emergency and hematology, compared to surgical, (67\% medical vs. $27 \%$ surgical; red blood cell transfusions, $2014)^{53}$. By contrast, samples in the included studies were less likely to include medical patients, or results from these groups were blended with perceptions from other patient and HCP groups. Perceptions of repeatedly transfused patients may be distinct from those of 'one-off' transfusion patients and their perceptions may influence patient behaviors, such as regular involvement in 
shared decision making or in transfusion safety monitoring ${ }^{4}$. In addition, no study explored patients' or HCPs' views of transfusion using platelets, widely used in hematology settings.

The present review identified existing studies of transfusion perceptions that predominantly focused on theories of risk. Other potential influences on perceptions of transfusions could be explored by drawing on a broader range of theories. A future study could be designed to use qualitative research methods to include interview questions related to the 'Necessity' of blood transfusion that could help to identify perceptions highlighting gaps where transfusions may be able to be spared.

Perceptions of patients and HCPs from the same hospitals could be explored using comparable patient- and HCP-tailored study materials, to investigate convergence or divergence of perceptions within a specific clinical area, providing patients with the opportunity to report their perceptions before or during the transfusion. By using qualitative research, patients' concerns or comfort with the transfusion could be discussed.

Strengths

Strengths of this review include the theoretical approach that has been taken by the review team to understand and synthesize the perceptions, and the development of a conceptual model of blood transfusion perceptions, making the themes of perceptions potentially more accessible. Use of the inductive synthesis method led to identification of some similarity in how patients and HCPs perceive transfusion (i.e. a level of correspondence in broad thematic areas, such as safety/risk). Likewise, areas of divergence in patients' and HCPs' perceptions, such as differences in concerns about blood transfusion, further support the need for greater patient-HCP collaboration, whereby patients can express perceptions that the HCP may themselves not hold or anticipate.

Limitations

A limitation stems from the lack of specification in studies of the blood component being investigated. HCPs from diverse clinical areas, investigated in the same study, may have been considering different blood components than their colleagues when reporting their perceptions, or 
patients reporting their perceptions may not have been aware of the blood component being (1) transfused. If patients lack information about the risks or reasons for the transfusion, this may impact their ability to fully evaluate the treatment's efficacy compared to any alternatives, as noted

\section{in the treatment perceptions literature ${ }^{54}$.}

\section{Conclusion}

In conclusion, this systematic review identified cognitive, emotional and behavioral themes of blood transfusion perceptions, themes that were shared by a wide range of patients and HCPs. Although

32 studies were included in this review, there is limited literature in this area. In particular, studies originating in low- to middle-income countries and studies focused on patients' and HCPs' perceptions for single clinical specialties are lacking. Despite rising numbers of research studies exploring the broad range of themes related to 'Safety/Risk' and 'Negative emotions' there was an unexplainable absence of any research on this topic between 2006 and 2010. As alternatives to transfusion are recommended to be considered when appropriate, future research should continue to expr

to explore perceptions of transfusion alternatives, especially when barriers have been cited for their use or consideration ${ }^{44,47}$. The increase in "Decision making" themes post 2011 coincides with the launch of PBM initiatives during this time $\mathrm{e}^{55,56}$. To further advance blood transfusion perceptions research, the use of qualitative methods in settings where transfusions are routinely provided are suggested as an area of future research.

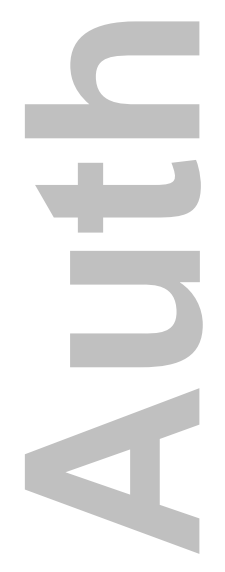


Acknowledgements:

$-\sqrt{1}$

We thank Andrea Patey (AP) from City, University of London, Dr Carolyn Doree from NHS Blood and Transplant and Professor Michael Murphy for their assistance with the review. We are also grateful to study authors who responded in request for study materials.
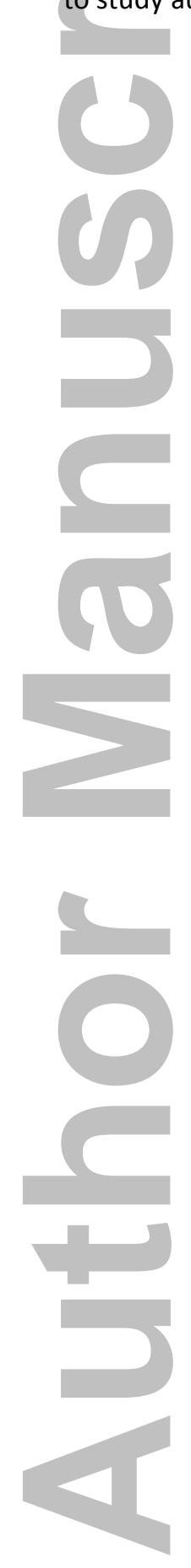

ScholarOne, 375 Greenbrier Drive, Charlottesville, VA, 229011 (434) 964-4100

This article is protected by copyright. All rights reserved. 


\section{References}

1. Carson JL, Guyatt G, Heddle NM, et al. Clinical practice guidelines from the AABB: Red blood cell transfusion thresholds and storage. JAMA 2016;316: 2025-35.

2. National Institute for Health and Care Excellence. Blood transfusion. (NICE guideline 24.) [monograph on the internet]. 2015. Available from: https://www.nice.org.uk/guidance/ng24, accessed 13th January 2016

3. Goodnough LT, Shander A. Patient blood management. Survey of Anesthesiology 2012;56: 278-9.

4. Davis RE, Vincent CA, Murphy MF. Blood transfusion safety: the potential role of the patient. Transfusion Medicine Reviews 2011;25: 12-23.

5. Goodnough LT. Risks of blood transfusion. Crit Care Med 2003;31: S678-86.

6. Ramström H, Afandi S, Elofsson K, Petersson S. Differences in beliefs between patients and pharmaceutical specialists regarding medications. Patient education and counseling 2006;62: 244-9.

7. Friedman MT, Bizargity P, Gilmore $\mathrm{S}$, Friedman A. Patient inclusion in transfusion medicine: current perspectives. International Journal of Clinical Transfusion Medicine 2015;3: 7-16.

8. Glanz K, Rimer BK. Theory at a glance: A guide for health promotion practice (2nd ed.). National Cancer Institute, NIH, Public Health Service; 2005.

9. Leventhal H, Nerenz DR, Steele DS. Illness representations and coping with health threats. In: Baum, A. Taylor, S.E. and Singer, J.E. (Eds.), Handbook of psychology and health.: Hillsdale, NJ: Erlbaum, 1984:219-52.

10. Horne R, Weinman J, Hankins M. The beliefs about medicines questionnaire: the development and evaluation of a new method for assessing the cognitive representation of medication. Psychology and health 1999;14: 1-24.

11. Perkins HA, Busch MP. Transfusion-associated infections: 50 years of relentless challenges and remarkable progress. Transfusion 2010;50: 2080-99.

12. Kmet LM, Lee RC, Cook LS. Standard quality assessment criteria for evaluating primary research papers from a variety of fields: Alberta Heritage Foundation for Medical Research, 2004.

13. Dixon-Woods $M$, Agarwal S, Jones D, Young B, Sutton A. Synthesising qualitative and quantitative evidence: a review of possible methods. Journal of Health Services Research \& Policy 2005;10: 45-53B.

14. Thomas DR. A general inductive approach to qualitative data analysis. [monograph on the internet]. $2003 . \quad$ Available from: http://www.frankumstein.com/PDF/Psychology/Inductive\%20Content\%20Analysis.pdf, accessed 24th June 2016

15. Thomas DR. A general inductive approach for analyzing qualitative evaluation data. American Journal of Evaluation 2006;27: 237-46.

16. Braun V, Clarke V. Using thematic analysis in psychology. Qualitative Research in Psychology 2006;3: 77-101.

17. Chung VC, Ma PH, Lau CH, Wong S, Yeoh EK, Griffiths SM. Views on traditional Chinese medicine amongst Chinese population: a systematic review of qualitative and quantitative studies. Health Expectations 2014;17: 622-36.

18. Amin M, Wilson K, Tinmouth A, Hébert P. Does a perception of increased blood safety mean increased blood transfusion? An assessment of the risk compensation theory in Canada. BMC Public Health 2004;4: 20-4.

19. Moxey A, O'connell D, Treloar C, Han P, Henry D. Blood transfusion and autologous donation: a survey of post-surgical patients, interest group members and the public. Transfusion Medicine 2005;15: 19-32.

20. Ngo LTB, Roberta; Custer, Brian. Risk perception and its role in attitudes toward blood transfusion: a qualitative systematic review. Transfusion Medicine Reviews 2013;27: 119-28. 
21. Cheung D, Lieberman L, Lin Y, Callum J. Consent for blood transfusion: do patients understand the risks and benefits? Transfusion Medicine 2014;24: 269-73.

22. Davis R, Vincent C, Sud A, Noel S, Moss R, Asgheddi M, Abdur-Rahman I, Murphy M. Consent to transfusion: patients' and healthcare professionals' attitudes towards the provision of blood transfusion information. Transfusion Medicine 2012;22: 167-72.

23. Luby SP, Niazt Q, Siddiquit S, Mujeeb SA, Fisher-Hoch S. Patients' perceptions of blood transfusion risks in Karachi, Pakistan. International Journal of Infectious Diseases 2001;5: 246.

24. Shah MS, Islam A, Rahman A, Rahman MM, Akter D, Afrin S. To evaluate the extent of awareness about hazards of blood transfusion among the blood recipients. Mymensingh medical journal 2012;21: 674-8.

25. Murphy M, Docherty S, Greenfield P. Survey of the information given to patients about blood transfusion and the need for consent before transfusion. Transfusion Medicine 1997;7: 287-8.

26. Khan MH, Watson HG, Dombrowski SU. Perceived hazards of transfusion: can a clinician tool help patients' understanding? Transfusion Medicine 2012;22: 294-7.

27. Graham ID, Fergusson D, Dokainish H, Biggs J, McAuley L, Laupacis A. Autologous versus allogeneic transfusion: patients' perceptions and experiences. Canadian Medical Association journal 1999;160: 989-95.

28. Lee SJ, Liljas B, Neumann PJ, Weinstein MC, Johannesson M. The impact of risk information on patients' willingness to pay for autologous blood donation. Medical care 1998;36: 116273.

29. Lee SJ, Neumann PJ, Churchill WH, Cannon ME, Weinstein MC, Johannesson M. Patients' willingness to pay for autologous blood donation. Health policy 1997;40: 1-12.

30. Court EL, Robinson JA, Hocken DB. Informed consent and patient understanding of blood transfusion. Transfusion Medicine 2011;21: 183-9.

31. Orme J, Still D, Day R, Evans J, Perkins P. The experiences of patients undergoing blood transfusion in a day hospice. International journal of palliative nursing 2013;19: 171-6.

32. Adams KW, Tolich D. Blood Transfusion: The Patient's Experience. The American Journal of Nursing 2011;111: 24-30.

33. Fitzgerald M, Hodgkinson B, Thorp D. Blood transfusion from the recipient's perspective. Journal of clinical nursing 1999;8: 593-600.

34. Treloar CJ, Hewitson PJ, Henderson KM, Harris G, Henry D, McGrath KM. Factors influencing the uptake of technologies to minimize perioperative allogeneic blood transfusion: An interview study of national and institutional stakeholders. Internal Medicine Journal 2001;31: 230-6.

35. Hartford E, Muanantatha O, Valigy VI, Salimo S, Ziman A, Deugarte DA. Transfusion practice and knowledge in Mozambique. Transfusion 2015;55: 1607-12.

36. Vetter TR, Adhami LF, Porterfield JR, Marques MB. Perceptions about blood transfusion: A survey of surgical patients and their anesthesiologists and surgeons. Anesthesia and Analgesia 2014;118: 1301-8.

37. Müller MC, de Haan RJ, Vroom MB, Juffermans NP. Evaluation of a multi-center randomised clinical trial on prophylactic transfusion of fresh frozen plasma: implications for future trials. Transfusion Medicine 2014;24: 292-6.

38. Heddle NM, Fung M, Hervig T, Szczepiorkowski ZM, Torretta L, Arnold E, Lane S, Murphy MF, Collaborative B. Challenges and opportunities to prevent transfusion errors: a Qualitative Evaluation for Safer Transfusion (QUEST). Transfusion 2012;52: 1687-95.

39. Islam R, Tinmouth AT, Francis JJ, Brehaut JC, Born J, Stockton C, Stanworth S, Eccles MP, Cuthbertson B, Hyde C, Grimshaw JM. A cross-country comparison of intensive care physicians' beliefs about their transfusion behaviour: a qualitative study using the Theoretical Domains Framework. Implementation science 2012;7: 93. 
40. Francis JJ, Stockton C, Eccles MP, Johnston M, Cuthbertson B, Grimshaw J, Hyde C, Tinmouth A, Stanworth SJ. Evidence-based selection of theories for designing behaviour change interventions: Using methods based on theoretical construct domains to understand clinicians' blood transfusion behaviour. British Journal of Health Psychology 2009;14: 625-46.

41. Cozzolongo R, Cuppone R, Petruzzi J, Stroffolini T, Manghisi OG. Approach of primary care physicians to hepatitis C: an educational survey from a Southern Italian area. The Journal of infection 2005;51: 396-400.

42. Leibovitz A, Baumoehl Y, Walach N, Kaplun V, Sigler E, Balan S, Habot B. Medical staff attitudes: views and positions regarding blood transfusion to terminally ill cancer patients. American Journal of Clinical Oncology 2004;27: 542-6.

43. Lee DH, Mehta MD, James PD. Differences in the perception of blood transfusion risk between laypeople and physicians. Transfusion 2003;43: 772-8.

44. Graham ID, Alvarez G, Tetroe J, McAuley L, Laupacis A. Factors influencing the adoption of blood alternatives to minimize allogeneic transfusion: the perspective of eight Ontario hospitals. Canadian journal of surgery 2002;45: 132-40.

45. Ferguson E, Farrell K, Lowe KC, James V. Perception of risk of blood transfusion: Knowledge, group membership and perceived control. Transfusion Medicine 2001;11: 129-35.

46. Lowe KC, Farrell K, Ferguson EM, James V. Current perceived risks of transfusion in the UK and relevance to the future acceptance of blood substitutes. Artificial cells, blood substitutes, and immobilization biotechnology 2001;29: 179-89.

47. Torella F, Haynes SL, Lardi A, O'Dwyer ST, McCollum CN. Unchanging attitudes to autologous transfusion in the UK. Transfusion Medicine 2001;11: 15-9.

48. Thonneau P, Quesnot S, Lhomme J-P, Testas P, Spira A. Evaluation by women consulting in a family planning centre of their risk of HIV infection. AIDS 1991;5: 549-53.

49. Salem-Schatz SR, Avorn J, Soumerai SB. Influence of clinical knowledge, organizational context, and practice style on transfusion decision making. Implications for practice change strategies. The Journal of the American Medical Association 1990;264: 476-83.

50. D'Souza RFC, Glynn MJ, Alstead E, Osonayo C, Foster GR. Knowledge of chronic hepatitis C among East London primary care physicians following the Deparment of Health's educational campaign. QJM - Monthly Journal of the Association of Physicians 2004;97: 3316.

51. Lazarus RS. Coping Theory and Research: Past, Present and Future. Psychosomatic Medicine 1993;55: 234-47.

52. SaBTO Advisory Committee on the Safety of Blood Tissues and Organs. Patient Consent for Blood Transfusion. [monograph on the internet]. 2011. Available from: https://www.gov.uk/government/uploads/system/uploads/attachment data/file/216586/d h 130715.pdf, accessed 24th June 2016

53. Tinegate H, Pendry K, Murphy M, Babra P, Grant-Casey J, Hopkinson C, Hyare J, Rowley M, Seeney $F$, Watson $D$, Wallis J. Where do all the red blood cells (RBCs) go? Results of a survey of RBC use in England and North Wales in 2014. Transfusion 2016;56: 139-45.

54. Horne R. Treatment perceptions and self-regulation. The Self-Regulation of Health and Illness Behaviour. London: Routledge, 2003.

55. Addison J, Gerrard R, Murphy M, Stanworth S. Patient Blood Management in England. AABB News 2013;August 2013: 6.

56. Leahy MF, Roberts H, Mukhtar SA, Farmer S, Tovey J, Jewlachow V, Dixon T, Lau P, Ward M, Vodanovich M. A pragmatic approach to embedding patient blood management in a tertiary hospital. Transfusion 2014;54: 1133-45. 

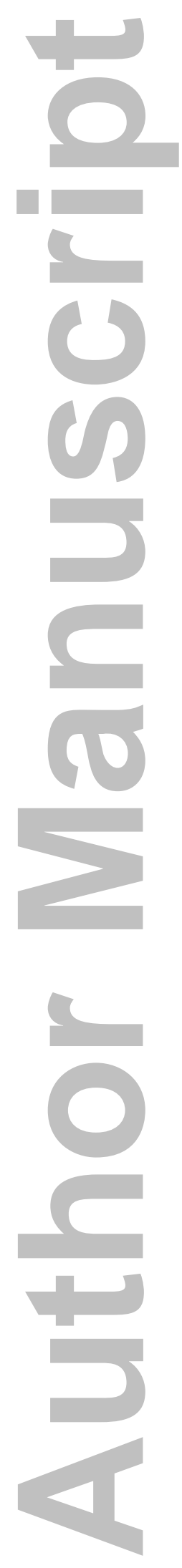
Table 1 Study inclusion criteria

No. Inclusion criterion

$1 \quad$ Full text English Language publication from a peer reviewed journal

$2 \quad$ Published since 1984

3 Assessing perceptions of blood transfusion of any blood component

4 Reporting empirical data about perceptions of blood transfusion through a primary study

5 Participant sample including patients and / or HCPs

6 Reported participant samples not below 18 years old or HCPs who treat patients below 18 years' old
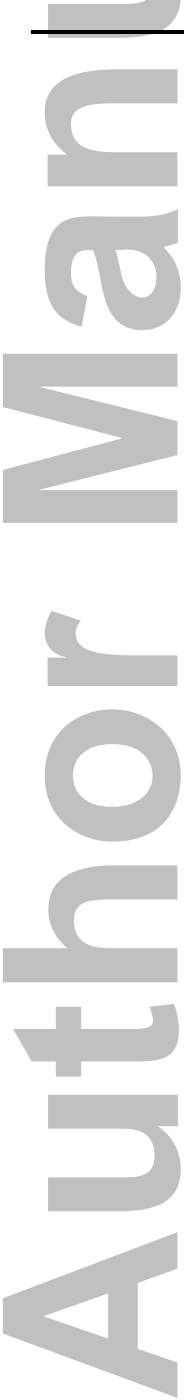

ScholarOne, 375 Greenbrier Drive, Charlottesville, VA, 229011 (434) 964-4100

This article is protected by copyright. All rights reserved. 
Table 2 Included studies and study characteristics

\begin{tabular}{|c|c|c|c|c|c|c|}
\hline Patient study & $\begin{array}{l}\text { Country \& sites } \\
\text { (n) }\end{array}$ & Research setting & Study design & $\begin{array}{l}\text { Samples included in } \\
\text { analysis }\end{array}$ & $\begin{array}{l}\text { Reported sample } \\
\text { characteristics }\end{array}$ & $\begin{array}{l}\text { Reported reasons for the } \\
\text { transfusion or diagnoses }(n)\end{array}$ \\
\hline $\begin{array}{l}\text { Cheung, e } \\
\text { (2014) }\end{array}$ & $\begin{array}{l}\text { Canada, } \\
\text { Toronto (1) }\end{array}$ & $\begin{array}{l}\text { Tertiary care } \\
\text { hospital }\end{array}$ & Cross-sectional & $\begin{array}{l}25 \text { patients prepared for a } \\
\text { transfusion }\end{array}$ & $\begin{array}{l}\text { Age: } 38-84 \text { (mean 61) Male 11, } \\
\text { Female } 14\end{array}$ & $\begin{array}{l}\text { Diagnoses: oncologic (19), } \\
\text { Myelodysplastic syndrome (2), } \\
\text { Not reported (4) }\end{array}$ \\
\hline $\begin{array}{l}\text { Orme et al., } \\
\text { (2013) }\end{array}$ & $\begin{array}{l}\text { UK, South } \\
\text { England (1) }\end{array}$ & Hospice & Interview & 10 transfusion recipients & $\begin{array}{l}\text { Age: } 67 \text { - } 95 \text { (mean 79.5) Male } \\
\text { 7, Female } 3\end{array}$ & $\begin{array}{l}\text { Diagnoses: myelodysplasia (7), } \\
\text { non-Hodgkin's lymphoma (1), } \\
\text { myelofibrosis (1), sideroplastic } \\
\text { anemia (1). }\end{array}$ \\
\hline $\begin{array}{l}\text { Davis et al., } \\
\text { (2012) }\end{array}$ & $\begin{array}{l}\text { UK, London \& } \\
\text { Oxford (2) }\end{array}$ & Secondary h/c & $\begin{array}{l}\text { Cross sectional } \\
\text { qualitative }\end{array}$ & $\begin{array}{l}110 \text { transfusion recipients } \\
\text { (post-operative + regular } \\
\text { recipients; ambulatory } \\
\text { hematology) }\end{array}$ & $\begin{array}{l}\text { Age: 18-93 (mean 60) Male 60, } \\
\text { Female } 50 \\
\text { Caucasian 77, Non-Caucasian } \\
33\end{array}$ & \\
\hline $\begin{array}{l}\text { Luby et a } \\
(2012)\end{array}$ & $\begin{array}{l}\text { Pakistan, } \\
\text { Karachi (12) }\end{array}$ & $\begin{array}{l}\text { Secondary } \mathrm{h} / \mathrm{c} \\
\text { (1) and tertiary } \\
\text { care centres (11) }\end{array}$ & Cross sectional & 141 transfusion recipients & $\begin{array}{l}\text { Age: (mean } 33 \text { ) Male } \\
\text { 50, Female } 91 \\
\text { Occupation }=80 \text { housewives, } \\
20 \text { manual labourers, \& } 20 \\
\text { office workers. }\end{array}$ & $\begin{array}{l}\text { Reason: surgical blood loss } \\
\text { (77), anemia (28), generalized } \\
\text { weakness (15) \& trauma (13). }\end{array}$ \\
\hline $\begin{array}{l}\text { Shah et al., } \\
\text { (2012) }\end{array}$ & $\begin{array}{l}\text { Dhaka, } \\
\text { Bangladesh (1) }\end{array}$ & Secondary $\mathrm{h} / \mathrm{c}$ & $\begin{array}{l}\text { Cross sectional/ } \\
\text { observational }\end{array}$ & $\begin{array}{l}126 \text { transfusion recipients } \\
\text { (transfusion medicine } \\
\text { dept.) }\end{array}$ & $\begin{array}{l}\text { Age: (mean } 33 \text { for males, } 37.9 \\
\text { females) Male 81, Female } 45\end{array}$ & \\
\hline $\begin{array}{l}\text { Adams et al., } \\
\text { (2011) }\end{array}$ & USA, Ohio (1) & Secondary $\mathrm{h} / \mathrm{c}$ & Interview & 21 transfusion recipients & $\begin{array}{ll}\text { Age: }(\mathrm{n}) & \\
18-30 & 2 \\
31-50 & 2 \\
51-70 & 7 \\
71-90 & 10 \\
\text { Male 5, Female 16 }\end{array}$ & $\begin{array}{l}\text { Reason: all anemia (diverse } \\
\text { range of causes). }\end{array}$ \\
\hline
\end{tabular}




\begin{tabular}{|c|c|c|c|c|c|c|}
\hline 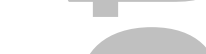 & & & & Transfusion & & \\
\hline $\begin{array}{l}\text { Fitzgerald et al., } \\
\text { (1999) }\end{array}$ & $\begin{array}{l}\text { Australia, } \\
\text { Adelaide (1) }\end{array}$ & Secondary h/c & Interview & 19 transfusion recipients & $\begin{array}{l}\text { Age: }(\mathrm{n}) \\
\text { 21-30: } 3 \\
\text { 31-50: } 4 \\
\text { 51-70: } 8 \\
\text { 71-90: } 4 \\
\text { Male 14, Female } 5\end{array}$ & $\begin{array}{l}\text { Diagnoses: cancer (6), clotting } \\
\text { disorders (2), organ failure (2), } \\
\text { emergency (3), surgery (6) }\end{array}$ \\
\hline $\begin{array}{l}\text { Murphy et al., } \\
\text { (1997) }\end{array}$ & UK, London (1) & Secondary h/c & Cross sectional & $\begin{array}{l}51 \text { transfusion recipients } \\
\text { (medical / surgical wards) }\end{array}$ & $\begin{array}{l}\text { Age: } 17-82 \text { years } \\
\text { Male } 34, \text { Female } 17\end{array}$ & \\
\hline $\begin{array}{l}\text { Khan et al., } \\
\text { (2012) }\end{array}$ & $\begin{array}{l}\text { UK, Scotland; } \\
\text { Aberdeen (1) }\end{array}$ & Secondary h/c & Cross sectional & $\begin{array}{l}14 \text { patients attending } \\
\text { surgical pre-assessment } \\
\text { clinic }\end{array}$ & None reported & \\
\hline $\begin{array}{l}\text { Graham et al., } \\
\text { (1999) }\end{array}$ & $\begin{array}{l}\text { Canada, Ottawa } \\
\text { (2) }\end{array}$ & Secondary $\mathrm{h} / \mathrm{c}$ & Cross sectional & $\begin{array}{l}80 \text { Cardiac patients ( } 40 \\
\text { PAD / } 40 \text { non-PAD) } \\
\text { \& } 73 \text { Orthopedic patients } \\
\text { (38 PAD / } 35 \text { non-PAD). }\end{array}$ & $\begin{array}{l}\text { Age: (mean) 59.0 Cardiac PAD / } \\
\text { 63.5 Cardiac non-PAD / } 63.2 \\
\text { Orthopedic PAD / 71.5 } \\
\text { Orthopedic non-PAD. } \\
\text { Male = 88 Cardiac PAD / } 80 \\
\text { Cardiac non-PAD / } 40 \text { male } \\
\text { Orthopedic PAD / } 34 \text { male } \\
\text { Orthopedic non-PAD. }\end{array}$ & $\begin{array}{l}\text { Reason: Range of surgical } \\
\text { procedures. }\end{array}$ \\
\hline $\begin{array}{l}\text { Lee et al., } \\
\text { (1998) }\end{array}$ & $\begin{array}{l}\text { USA, } \\
\text { Massachusetts } \\
\text { \& Maine (3) }\end{array}$ & Secondary h/c & $\begin{array}{l}\text { Randomized } \\
\text { between } \\
\text { subjects design }\end{array}$ & 412 patients (prior to $P A D$ ) & $\begin{array}{l}\text { Age (mean) } 56.05(15.14) \\
\text { Female } 230 \\
\text { Mean annual income (\$) 44,924 } \\
\text { College education } 66\end{array}$ & $\begin{array}{l}\text { Patients scheduled for } \\
\text { autologous donation before } \\
\text { planned surgical procedures }\end{array}$ \\
\hline $\begin{array}{l}\text { Lee et al., } \\
\text { (1997) }\end{array}$ & USA, Boston (1) & Secondary $\mathrm{h} / \mathrm{c}$ & Cross sectional & $\begin{array}{l}235 \text { patients (prior / } \\
\text { following PAD) }\end{array}$ & $\begin{array}{l}\text { Age: }(\text { mean) } 50.45 \quad \text { Mean } \\
\text { Female } 63 \% \quad \begin{array}{l}\text { household income }=\$ 57993 \\
\text { College education } 64 \%\end{array}\end{array}$ & $\begin{array}{l}\text { Patients scheduled for } \\
\text { autologous donation before } \\
\text { planned surgical procedures }\end{array}$ \\
\hline $\begin{array}{l}\text { Court et al., } \\
\text { (2011) }\end{array}$ & UK, Swindon (1) & Secondary $\mathrm{h} / \mathrm{c}$ & Cross sectional & $\begin{array}{l}132 \text { transfusion recipients } \\
32 \text { non-recipients (blood } \\
\text { cross-matched) }\end{array}$ & $\begin{array}{l}\text { Age: } 21-84 \text { years } \quad \text { Male } \\
\text { 141, Female } 201\end{array}$ & $\begin{array}{l}\text { Post-operative: } 66 \text { transfusion } \\
\text { recipients ( } 66 \cdot 7 \% \text { elective) / } 26 \\
\text { non-recipients ( } 80 \cdot 8 \% \\
\text { elective). }\end{array}$ \\
\hline
\end{tabular}




\begin{tabular}{|c|c|c|c|c|c|c|}
\hline $\begin{array}{l}\text { Moxey et al., } \\
\text { (2005) }\end{array}$ & $\begin{array}{l}\text { Australia, } \\
\text { Hunter \& } \\
\text { Central Coast } \\
\text { Regions (multi- } \\
\text { site) }\end{array}$ & $\begin{array}{l}\text { Primary } \mathrm{h} / \mathrm{c} \text {, } \\
\text { secondary } \mathrm{h} / \mathrm{c} \text {, } \\
\text { rehabilitation } \\
\text { clinics }\end{array}$ & Interview & $\begin{array}{l}23 \text { transfusion recipients } \\
6 \text { PAD recipients } \\
9 \text { other (post-surgical } \\
\text { patients) * }\end{array}$ & $\begin{array}{l}\text { Age: }(n) \\
\text { 30-39: } 0 \\
40-49: 3 \\
50-59: 2 \\
60-69: 9 \\
70-79: 18 \\
80+: 6 \\
\text { Male 22, Female } 16\end{array}$ & \\
\hline HCP Study & $\begin{array}{l}\text { Country \& sites } \\
\text { (n) }\end{array}$ & Research setting & Study design & $\begin{array}{l}\text { Samples included in } \\
\text { analysis }\end{array}$ & $\begin{array}{l}\text { Reported sample } \\
\text { characteristics }\end{array}$ & Years of clinical experience \\
\hline $\begin{array}{l}\text { Hartford et al. } \\
\text { (2015) }\end{array}$ & $\begin{array}{l}\text { Mozambique } \\
\text { (3) }\end{array}$ & $\begin{array}{l}\text { Workplace } \\
\text { (hospital) }\end{array}$ & Cross sectional & $\begin{array}{l}216 \text { Physicians }(94 \%) \\
\text { nurses }(2 \%) \& \text { technicians } \\
(4 \%)^{*}\end{array}$ & $\begin{array}{l}\text { Reported physicians' specialty: } \\
\text { internal medicine (36\%), } \\
\text { surgery (34\%), paediatrics } \\
(19 \%) \text {, anaesthesia (10\%), and } \\
\text { other (1\%). }\end{array}$ & $\begin{array}{l}47 \% \text { were postgraduate } \\
\text { (resident) trainees }\end{array}$ \\
\hline $\begin{array}{l}\text { Vetter et al } \\
\text { (2014) }\end{array}$ & $\begin{array}{l}\text { US, Birmingham } \\
\text { Alabama (1) }\end{array}$ & Secondary h/c & Cross sectional & $\begin{array}{l}73 \text { Anesthesiologists' } \\
(n=34) \& \text { surgeons }(n=39)\end{array}$ & $\begin{array}{l}\text { Age: } 47 \text { (mean) in years } \\
\text { Gender }(m=68) \text { : Male 54, } \\
\text { female } 14\end{array}$ & $\begin{array}{l}\text { Post residency practice } \\
\text { duration (mean } 14 \text { years) }\end{array}$ \\
\hline $\begin{array}{l}\text { Müller et al., } \\
\text { (2014) }\end{array}$ & Netherlands (4) & Secondary h/c & Cross sectional & $\begin{array}{l}46 \text { Intensive Care Unit } \\
\text { (ICU) physicians \& fellows }\end{array}$ & $\begin{array}{l}\text { Age: } 20-35 \text { year } 24 \% \\
36-50 \text { year } 63 \%, 51-65 \text { year }\end{array}$ & \\
\hline & & & & & $\begin{array}{l}13 \% \\
\text { Gender: } 65 \% \text { male }\end{array}$ & $\begin{array}{l}\text { Fellow training in intensive } \\
\text { care } 28 \%\end{array}$ \\
\hline $\begin{array}{l}\text { Heddle et al., } \\
\text { (2012) }\end{array}$ & $\begin{array}{l}\text { Canada, UK, } \\
\text { Norway, Italy, } \\
\text { USA (6 site: } 2 \text { in } \\
\text { US) }\end{array}$ & Secondary h/c & $\begin{array}{l}\text { Interview }(n=7) \\
\& \text { focus group } \\
(n=12)\end{array}$ & $\begin{array}{l}72 \text { in/outpatient nurses } \\
\text { and physicians (Italy only) } \\
\text { sampled from diverse } \\
\text { clinical areas* }\end{array}$ & & \\
\hline $\begin{array}{l}\text { Islam et al., } \\
\text { (2012) }\end{array}$ & $\begin{array}{l}\text { Canada, UK } \\
\text { (multi-site) }\end{array}$ & Secondary h/c & Interview & 10 ICU physicians & Gender: 9 male, 1 female & $\begin{array}{l}\text { Variations in training \& } \\
\text { practice in transfusion }\end{array}$ \\
\hline $\begin{array}{l}\text { Francis et al., } \\
\text { (2009) }\end{array}$ & $\begin{array}{l}\text { UK, England \& } \\
\text { Scotland (multi- } \\
\text { site) }\end{array}$ & Secondary $\mathrm{h} / \mathrm{c}$ & Interview & $11 \mathrm{ICU}$ consultants & $\begin{array}{l}\text { Gender: } 10 \text { male, } 1 \text { female } \\
\text { Age: } 36-52 \text { years }\end{array}$ & 1 to 21 years \\
\hline
\end{tabular}




\begin{tabular}{|c|c|c|c|c|c|c|}
\hline $\begin{array}{l}\text { Cozzolongo et } \\
\text { al., (2005) }\end{array}$ & $\begin{array}{l}\text { Italy, Apulia } \\
\text { region (multi- } \\
\text { site) }\end{array}$ & Primary h/c & $\begin{array}{l}\text { Cohort study } \\
\text { design }\end{array}$ & $\begin{array}{l}306 \text { (time } 1 \text { )/ } 170 \text { (time } \\
\text { 2) primary care physicians }\end{array}$ & & \\
\hline $\begin{array}{l}\text { D'Souza et al., } \\
\text { (2004) }\end{array}$ & $\begin{array}{l}\text { UK, London } \\
\text { (multi-site) }\end{array}$ & Primary h/c & Mixed methods & $488 \mathrm{GPs}$ & & \\
\hline $\begin{array}{l}\text { Amin et al., } \\
\text { (2004) }\end{array}$ & $\begin{array}{l}\text { Canada, five } \\
\text { provinces } \\
\text { (multi-site) }\end{array}$ & $\begin{array}{l}\text { Sourced via } \\
\text { Canadian } \\
\text { Medical } \\
\text { Association } \\
\text { Directory (2002) }\end{array}$ & Cross sectional & $\begin{array}{l}45 \text { physicians ( } 28 \\
\text { internists, } 10 \\
\text { cardiovascular surgeons \& } \\
7 \text { haematologists) }\end{array}$ & & \\
\hline $\begin{array}{l}\text { Leibovitz et al., } \\
\text { (2004) }\end{array}$ & $\begin{array}{l}\text { Israel (multi- } \\
\text { site) }\end{array}$ & Secondary h/c & Cross sectional & $\begin{array}{l}274 \text { physicians ( } 79 \\
\text { Internists, } 69 \text { oncologists, } \\
79 \text { Geriatricians, } 47 \text { family } \\
\text { physicians) } \\
74 \text { nurses (oncology } \\
\text { \&internal medicine wards) }\end{array}$ & $\begin{array}{l}\text { Gender ( } \mathrm{n} \text { female / male): } \\
\text { Internists } 16 \text { / } 63 \\
\text { Oncologists } 24 \text { / } 45 \\
\text { Geriatricians } 21 \text { / } 58 \\
\text { Family physicians } 26 \text { / } 21 \\
\text { Nurses } 72 \text { / } 2 \\
\text { Age (mean): Internists } 47 \\
\text { Oncologists } 49 \text {, Geriatricians } \\
\text { 53, Family physicians 44, } \\
\text { Nurses } 43\end{array}$ & $\begin{array}{l}\text { Years of practice (mean) } \\
\text { Internists } 20 \text {, Oncologists } 21 \text {, } \\
\text { Geriatricians } 25 \text {, Family } \\
\text { physicians } 17, \text { Nurses } 20 .\end{array}$ \\
\hline $\begin{array}{l}\text { Lee et al., } \\
\text { (2003) }\end{array}$ & $\begin{array}{l}\text { Canada, } \\
\text { Kingston } \\
\text { Ontario (1) }\end{array}$ & Secondary h/c & Cross sectional & $\begin{array}{l}33 \text { physicians, } 43 \text { residents } \\
\text { ( } 21 \text { family medicine, } 19 \\
\text { internal medicine \& } 17 \\
\text { anaesthesia) }\end{array}$ & $\begin{array}{l}\text { Gender: } 51 \% \text { female } \\
\text { Age: (mean) } 33 \\
\text { Family status: } 54 \% \text { married, } \\
30 \% \text { with children }\end{array}$ & \\
\hline $\begin{array}{l}\text { Graham, } \\
\text { (2002) }\end{array}$ & $\begin{array}{l}\text { Canada, Ontario } \\
\text { (8) }\end{array}$ & Secondary h/c & Interview & $\begin{array}{l}19 \text { hospital chiefs or } \\
\text { representatives from } \\
\text { surgery }(n=7) \text {, anaesthesia } \\
(n=3) \text {, transfusion } \\
\text { medicine/hematology or } \\
\text { laboratory medicine }(n=7) \\
\text { and pharmacy }(n=2) \text {. }\end{array}$ & & \\
\hline
\end{tabular}




\begin{tabular}{|c|c|c|c|c|c|}
\hline $\begin{array}{l}\text { Ferguson et al., } \\
\text { (2001) }\end{array}$ & $\begin{array}{l}\text { England, Trent } \\
\text { region (multi- } \\
\text { site) }\end{array}$ & Primary $\mathrm{h} / \mathrm{c}$ & $\begin{array}{l}\text { One-way } \\
\text { between } \\
\text { subjects design }\end{array}$ & 88 GPs, 143 , Anaesthetists & \\
\hline $\begin{array}{l}\text { Lowe et al., } \\
\text { (2001) }\end{array}$ & $\begin{array}{l}\text { England, Trent } \\
\text { region (multi- } \\
\text { site) }\end{array}$ & Primary $\mathrm{h} / \mathrm{c}$ & Cross sectional & 88 GPs, 143, Anaesthetists & $\begin{array}{l}\text { Gender: } 264 \text { male, } 233 \text { female } \\
\text { Age (mean): } 35.8\end{array}$ \\
\hline $\begin{array}{l}\text { Torella et al., } \\
\text { (2001) }\end{array}$ & $\begin{array}{l}\text { England, north- } \\
\text { west region } \\
\text { (multi-site) }\end{array}$ & Secondary h/c & $\begin{array}{l}\text { Cohort study } \\
\text { design }\end{array}$ & $\begin{array}{l}571 \text { surgeons n per year: } \\
151 \text { (1990), } 226 \text { (1994) \& } \\
194 \text { (1999) } \\
\text { (sampled from diverse } \\
\text { clinical areas) * }\end{array}$ & \\
\hline $\begin{array}{l}\text { Treloar et al., } \\
(2001)\end{array}$ & $\begin{array}{l}\text { Australia, } \\
\text { (multi-site) }\end{array}$ & Secondary h/c & Interview & $\begin{array}{l}12 \text { prominent clinicians, } 12 \\
\text { surgeons, } 14 \text { anaesthetists }\end{array}$ & \\
\hline $\begin{array}{l}\text { Thonneau et } \\
\text { al., (1991) }\end{array}$ & $\begin{array}{l}\text { France, Bicetre } \\
\text { (1) }\end{array}$ & Primary $\mathrm{h} / \mathrm{c}$ & Cross sectional & 6 doctors (family planning) & \\
\hline $\begin{array}{l}\text { Salem-Schatz et } \\
\text { al., (1990) }\end{array}$ & USA, (3) & Secondary h/c & $\begin{array}{l}\text { Cross sectional } \\
\text { survey }\end{array}$ & $\begin{array}{l}76 \text { surgeons, } 46 \\
\text { anesthesiologists }\end{array}$ & \\
\hline
\end{tabular}

Clinical role: $\mathrm{n}=50$ attending physicians $\& 72$ residents.

* Decision rule applied - non-eligible samples (i.e. * pediatricians, post-surgical patients) represent less than $50 \%$ of the total sample, data inseparable from other samples' data, therefore all data extracted. (1)

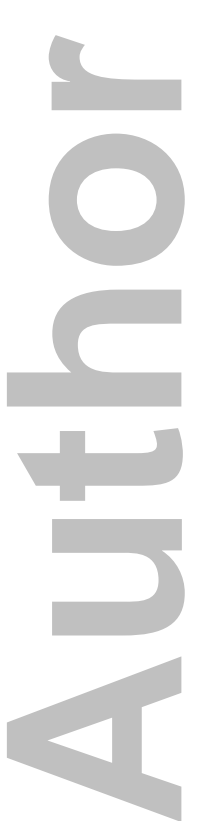




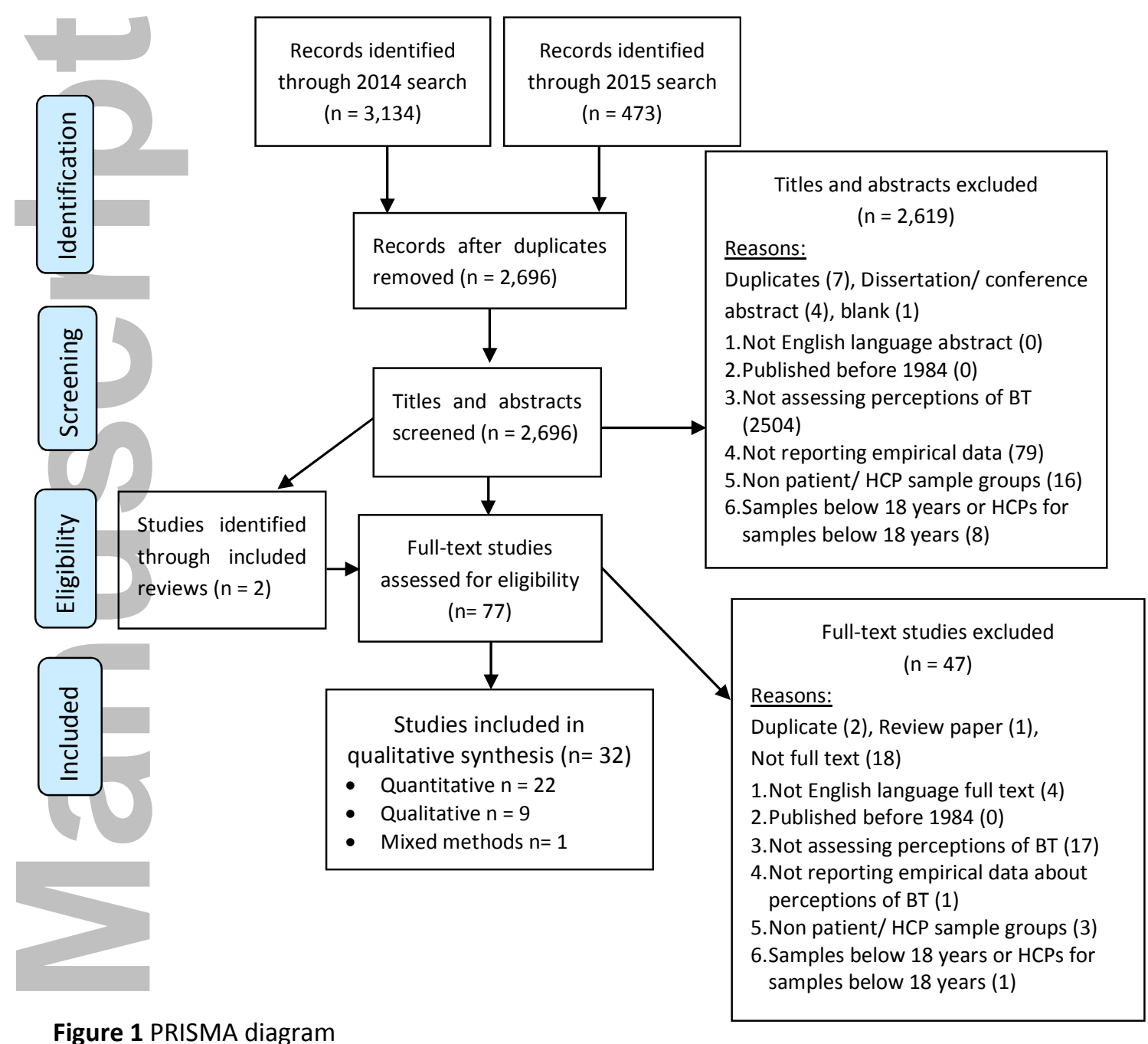

Figure 1 PRISMA diagram

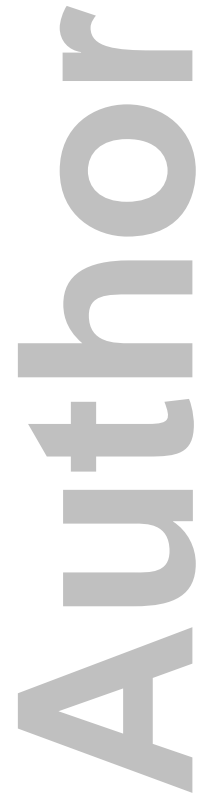




\section{Cognitive, emotional}

\section{Behavioural}

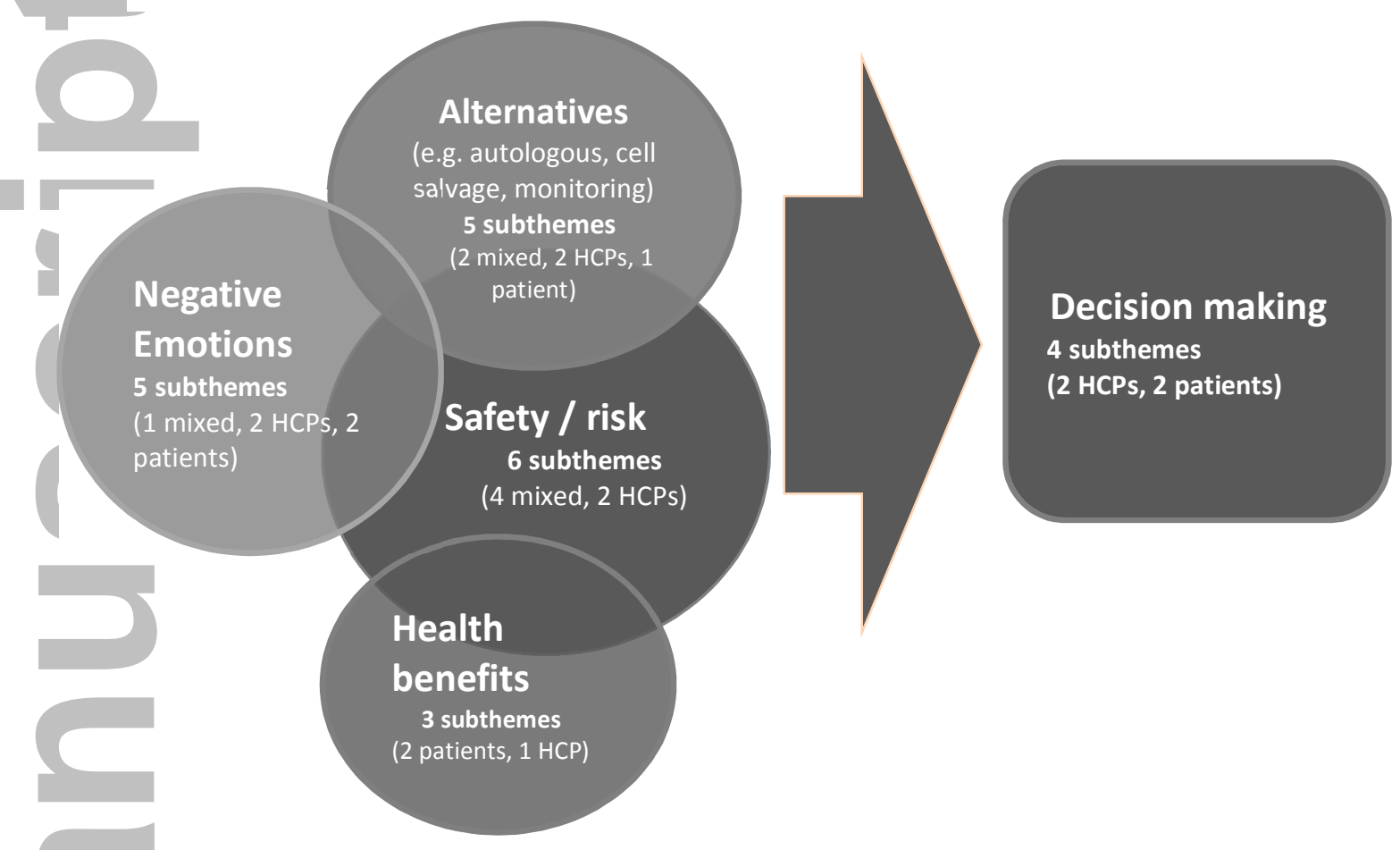

90

Figure 2 Conceptual model of blood transfusion perceptions based on qualitative synthesis of systematic review findings

Note. Text within each theme of the model shows the number of subthemes assigned to the model, at stage 1 of the synthesis, and whether these subthemes represent patients', HCPs' or mixed (both groups') perceptions. 


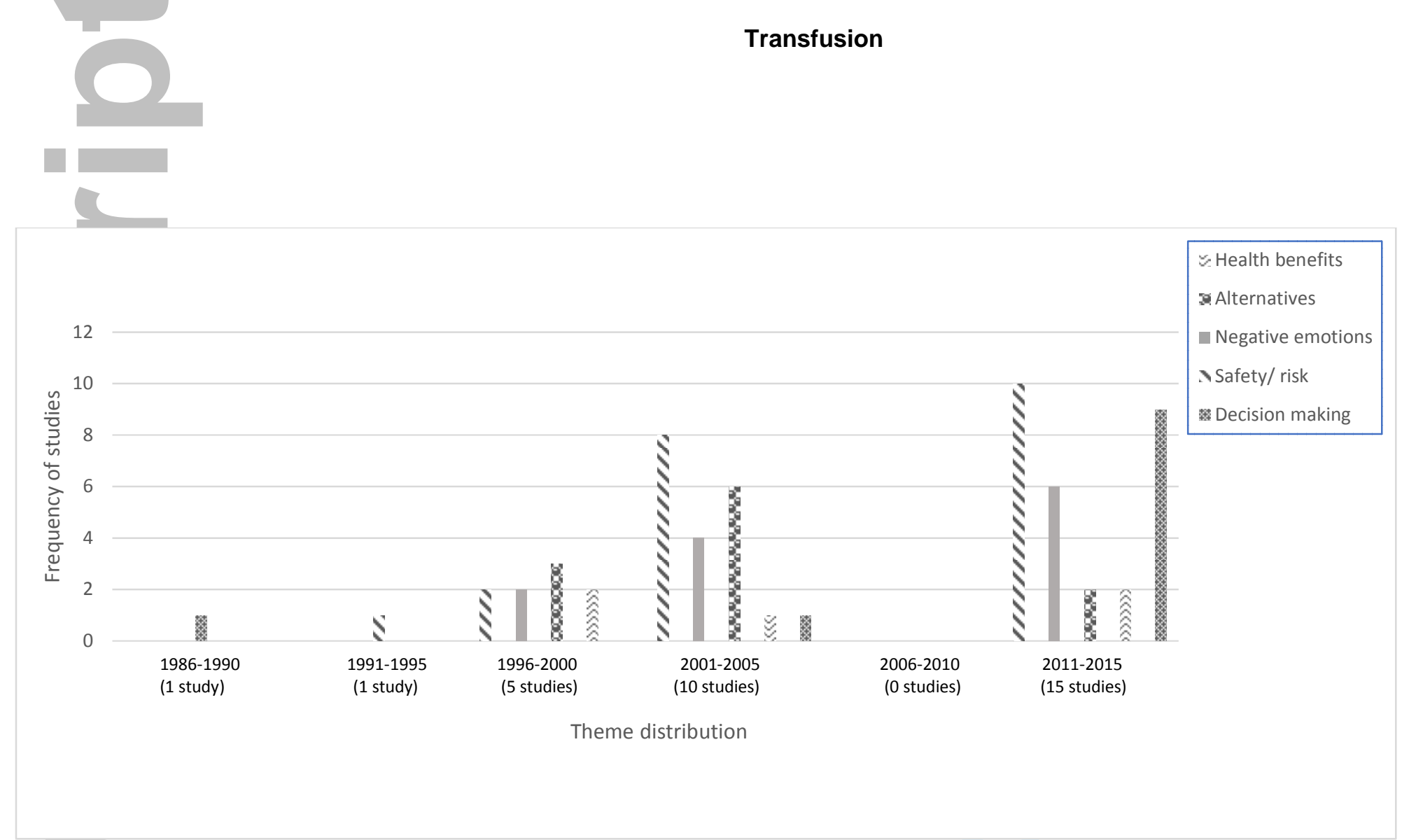

Figure 3 Reported themes of perceptions by publication years 
Patients' and Health Care Professionals' Perceptions of Blood Transfusion: A Systematic Review

\section{Appendix A}

Pilot search strategy:

University of York Centre for Reviews and Dissemination and The Cochrane Database of Systematic Reviews

perception* or representation* or belie* AND blood transfusion

Systematic review search strategy:

Embase search strategy for Cochrane CENTRAL and Database of Systematic Reviews (CDSR), Database of Abstracts of Reviews of Effects (DARE), MEDLINE, EMBASE

1 BLOOD TRANSFUSION.ti,ab.

2 (transfus* or pretransfus* or posttransfus* or retransfus* or red cell* or red blood cell* or platelets* or fresh plasma or frozen plasma or FFP or platelet concentrate*).ti.

3 (pretransfus* or posttransfus* or retransfus* or red cell transfusion* or red blood cell transfusion* or platelet transfusion* or plasma transfusion* or fresh plasma or frozen plasma or FFP or platelet concentrate*).ab

4 (blood adj3 (use* or usage* or requir* or administ* or need*)).ti

5 (blood product* or blood component* or blood management or blood replacement)).ti.

61 or 2 or 3 or 4 or 5

7 ((BLOOD TRANSFUSION or (transfus* or pretransfus* or posttransfus* or retransfus* or red cell* or red blood cell* or platelets* or fresh plasma or frozen plasma or FFP or platelet concentrate*) or (pretransfus* or posttransfus* or retransfus* or red cell transfusion* or red blood cell transfusion* or platelet transfusion* or plasma transfusion* or fresh plasma or frozen plasma or FFP or platelet concentrate*) or (blood adj3 (use* or usage* or requir* or administ* or need*)) or (blood product* or blood component* or blood management or blood replacement)) adj4 (percei* or perception or belie* or attitude* or experience* or perspective* or thought* or knowledge or representation* or view*)).ti,ab.

8 (medic or medics or medical staff or clinician* or doctor* or consultant* or registrar* or healthcare* or health worker* or nurs* or hospital staff or personnel* or clinical staff* or patient* or physician* or recipient* or technician* or practitioner*).ti,ab.

\section{7 and 8}

10 limit 9 to (human and $y r=" 1984-2014 ")$

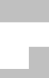

\section{EBSCOhost search strategy for PsycINFO, PsyARTICLES}

S1 TIBLOOD TRANSFUSION

\section{S2 AB BLOOD TRANSFUSION}

S3 TI transfus* or pretransfus* or posttransfus* or retransfus* or red cell* or red blood cell* or platelets* or fresh plasma or frozen plasma or FFP or platelet concentrate*

S4 AB pretransfus* or posttransfus* or retransfus* or red cell transfusion* or red blood cell transfusion* or platelet transfusion* or plasma transfusion* or fresh plasma or frozen plasma or FFP or platelet concentrate* 
Patients' and Health Care Professionals' Perceptions of Blood Transfusion: A Systematic Review

S5 TI blood N3 (use* or usage* or requir* or administ* or need*))

S6 TI blood product* or blood component* or blood management or blood replacement)

S7 TI (percei* or perception or belie* or attitude* or experience* or perspective* or thought* or knowledge or representation* or view*)

S8 $A B$ (percei* or perception or belie* or attitude* or experience* or perspective* or thought* or knowledge or representation* or view*)

S9 S1 OR S2 OR S3 OR S4 OR S5 OR S6 N4 (S7 OR S8)

S10 TI (medic or medics or medical staff or clinician* or doctor* or consultant* or registrar* or healthcare* or health worker* or nurs* or hospital staff or personnel* or clinical staff* or patient* or physician* or recipient* or technician* or practitioner*)

S11 AB (medic or medics or medical staff or clinician* or doctor* or consultant* or registrar* or healthcare* or health worker* or nurs* or hospital staff or personnel* or clinical staff* or patient* or physician* or recipient* or technician* or practitioner*)

S12 S10 OR S11

S11 S9 AND S12

(date range and human limiters were applied)

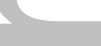

90
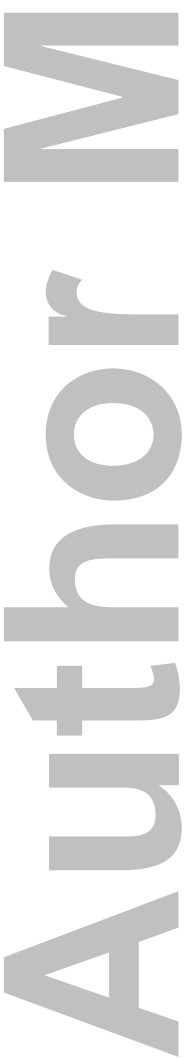

ScholarOne, 375 Greenbrier Drive, Charlottesville, VA, 229011 (434) 964-4100

This article is protected by copyright. All rights reserved. 
Patients' and Health Care Professionals' Perceptions of Blood Transfusion: A Systematic Review

\section{Appendix B}

Table of theories identified in the review

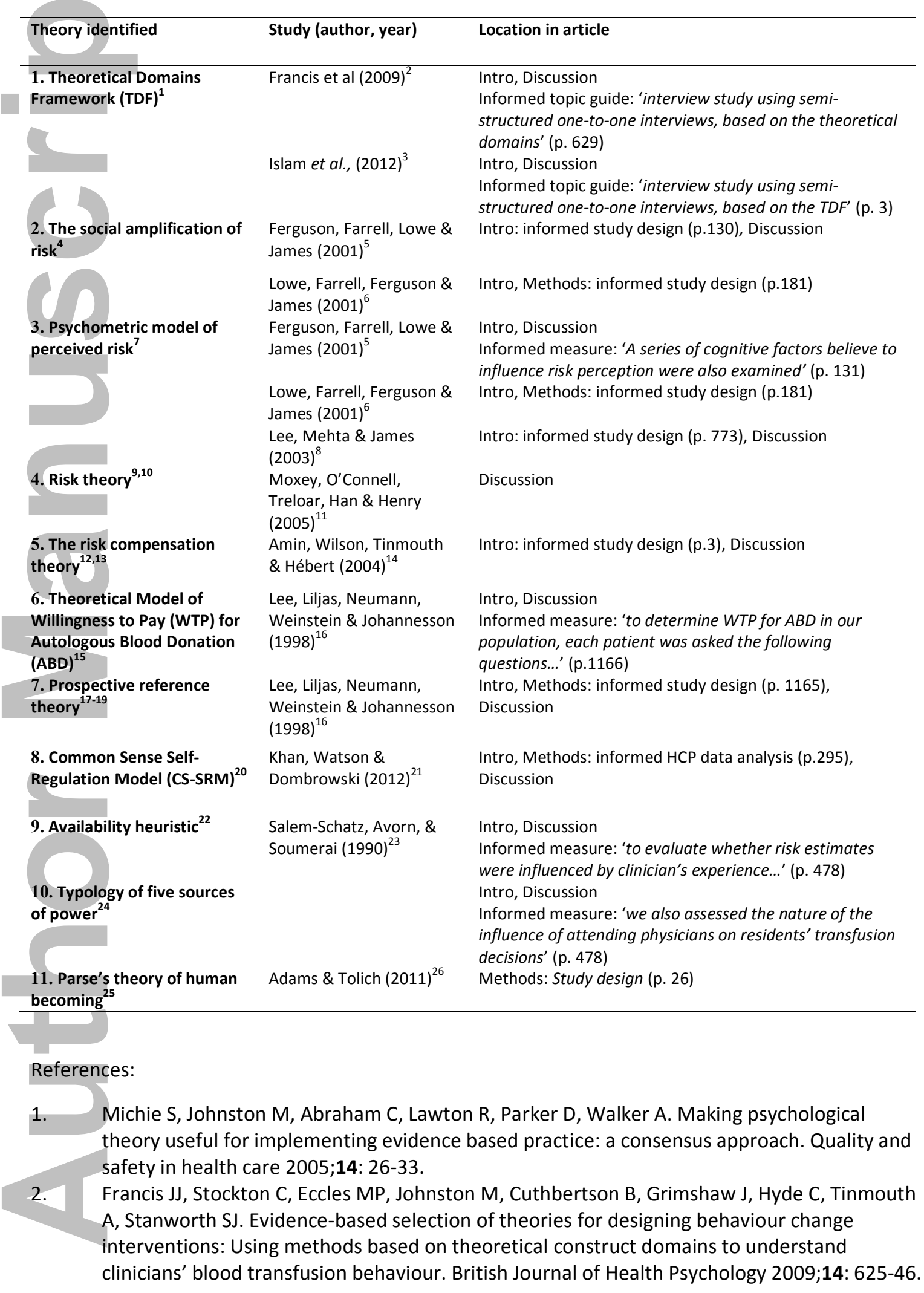


Patients' and Health Care Professionals' Perceptions of Blood Transfusion: A Systematic Review

3. Islam R, Tinmouth AT, Francis JJ, Brehaut JC, Born J, Stockton C, Stanworth S, Eccles MP, Cuthbertson B, Hyde C, Grimshaw JM. A cross-country comparison of intensive care physicians' beliefs about their transfusion behaviour: a qualitative study using the Theoretical Domains Framework. Implementation science 2012;7: 93.

4. Pigeon N, Hood C, Jones D, Turner B, Gibson R. Risk perception Risk: Analysis, Perception and Management. London: Royal Society, 1992.

5. Ferguson E, Farrell K, Lowe KC, James V. Perception of risk of blood transfusion: Knowledge, group membership and perceived control. Transfusion Medicine 2001;11: 129-35.

6. Lowe KC, Farrell K, Ferguson EM, James V. Current perceived risks of transfusion in the UK and relevance to the future acceptance of blood substitutes. Artificial cells, blood substitutes, and immobilization biotechnology 2001;29: 179-89.

7. Slovic P. Perception of risk. Science 1987;236: 280-5.

8. Lee DH, Mehta MD, James PD. Differences in the perception of blood transfusion risk between laypeople and physicians. Transfusion 2003;43: 772-8.

9. Giddens A. Modernity and Self-identity Self and Society in the Late Modern Age. Cambridge: Polity Press, 1991.

10. Beck U. Risk Society: Towards a New Modernity. London: Sage Publications, 1992.

11. Moxey A, O'connell D, Treloar C, Han P, Henry D. Blood transfusion and autologous donation: a survey of post-surgical patients, interest group members and the public. Transfusion Medicine 2005;15: 19-32.

12. Wilde G. The theory of risk homeostatis: implications for safety and health. Risk Analysis 1992;2: 209-58.

13. Wilde G. Risk homeostatis theory and its promise for improved safety. In: Trimpop RM WG, ed. Challenges to accident prevention: the issue of risk compensation processes. Groningen: Styx Publications, 1994.

14. Amin M, Wilson K, Tinmouth A, Hébert P. Does a perception of increased blood safety mean increased blood transfusion? An assessment of the risk compensation theory in Canada. BMC Public Health 2004;4: 20-4.

15. Eastaugh S. Valuation of the benefits of risk free blood. Willingness to pay for hemoglobin solutions. Int J Tech Assess Health Care 1991;7.

16. Lee SJ, Liljas B, Neumann PJ, Weinstein MC, Johannesson M. The impact of risk information on patients' willingness to pay for autologous blood donation. Medical care 1998;36: 116273.

17. Viscusi K. Prospective reference theory: toward an explanation of the paradoxes. J Risk Uncertainty 1989;2.

18. Viscusi K. Fatal tradeoffs: Public and private responsibilites for risk. New York: Oxford University Press, 1992.

19. Smith V. Environmental risk perception and valuation: Conventional versus prospective reference theory. In: Bromley DW S, K, ed. The social response to environmental risk: Policy formulation in an age of uncertainty. Dordrecht: Kluwer Academic Publishers, 1992.

20. Leventhal $\mathrm{H}$, Brissette I, Leventhal EA. The Common-sense model of self-regulation of health and illness. In: In L. D. Cameron \& H. Leventhal (Eds.), ed. The self-regulation of health and illness behaviour: London and New York: Routledge, 2003:42-65.

21. Khan MH, Watson HG, Dombrowski SU. Perceived hazards of transfusion: can a clinician tool help patients' understanding? Transfusion Medicine 2012;22: 294-7.

22. Tversky A, D K. Availability: a heuristic for judging frequency and probability. Cognitive Psychol. 1973;5: 207-32.

23. Salem-Schatz SR, Avorn J, Soumerai SB. Influence of clinical knowledge, organizational context, and practice style on transfusion decision making. Implications for practice change strategies. The Journal of the American Medical Association 1990;264: 476-83. 
Patients' and Health Care Professionals' Perceptions of Blood Transfusion: A Systematic Review

24. French JJ, Raven B. The bases of social power. In: Cartwright D, ed. Studies in Social Power: University of Michigan, 1959:150-67.

25. McEwen M, Wills E. Theoretical basis for nursing. Philadelphia: Lippincott Williams and Wilkins, 2007.

26. Adams KW, Tolich D. Blood Transfusion: The Patient's Experience. The American Journal of Nursing 2011;111: 24-30.

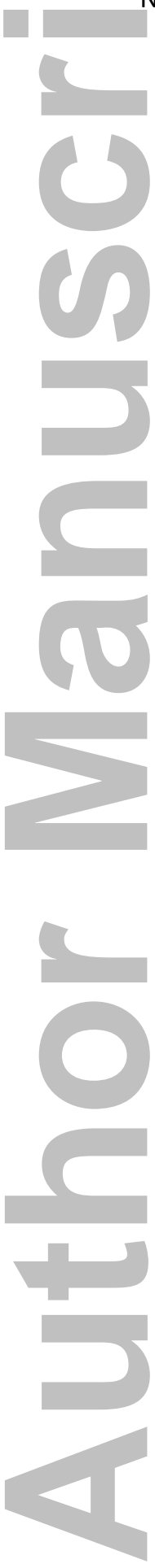

ScholarOne, 375 Greenbrier Drive, Charlottesville, VA, 229011 (434) 964-4100

This article is protected by copyright. All rights reserved. 
Patients' and Health Care Professionals' Perceptions of Blood Transfusion: A Systematic Review

\section{Appendix C}

Themes and subthemes with quotations

Extracted data
Example of extracted content of perceptions reported
by authors / participant quotes (italics)
$61.5 \%$ of 26 post-operative patients viewed transfusion
risk as less than surgical risk (p.186) ${ }^{1}$.
"Blood has the potential to kill; therefore, it is not like
another medication" [Nurse] (p.1690)
For 76 physicians and trainees, blood transfusion was of
intermediate ranking [from 10 hazards, i.e. nuclear
reactors, caffeine, sharing injection needles, genetically
modified foods] in [terms of] dread and severity and
knowledge and control' (p.774)

$50 \%$ of 482 GPs reported that blood transfusion in the 1990 s carried a high hepatitis C infection risk (p.333) ${ }^{4}$. $87 \%$ of 38 post-operative patients perceived a low risk of HIV from allogeneic blood transfusion (p.24) .

75 GPs and 135 Anaesthetists rated acute reaction (40 / $33 \%)$ as more likely than delayed reaction (1/6\%) $(\text { p.183) })^{6}$.

$67.5 \%$ of 126 patients in Bangladesh rated allergic reaction as most possible from a transfusion (p. 677) ${ }^{7}$.

None of $n=75$ GPs and $n=135$ Anaesthetists rated there to be a risk of death from blood transfusion (p. 183) ${ }^{6}$. $5 \%$ of 126 patients in Bangladesh thought that there was a risk of death from a blood transfusion (p. 677) ${ }^{7}$.

'The current safety of the blood supply was suggested as a factor decreasing the perceived need for any bloodsparing technology' (p.135). $19 \%$ of 73 physicians rated blood transfusions as "very often risky" (score of 4) or "always risky" (score of 5) $(1304)^{9}$

$29 \%$ of 38 post-surgical patients voiced concern with receiving allogeneic blood, mainly due to concern towards contracting a disease or infection (91\%), receiving wrong blood type (18\%) or adequacy of screening process (9\%)' (p.23)

$93 \%$ of 45 physicians would be concerned and reduce the level of blood products utilization following a new viral and/or bacterial threat in the future $(p .3)^{10}$.

"I might be concerned in some situations about watching and waiting" (p.635) $)^{11}$.

For 38 medics there was some concern about the inappropriate use of PAD blood in that it was 'poorly targeted' (i.e. collected in situations where it was unlikely to be used) and given back to the patient regardless of need (p.234) $)^{12}$.

'Apart from the worry of infection from a blood transfusion [for patients], it was not seen to be an uncomfortable procedure. (p.598) $)^{13}$.

\section{Stage 1 of synthesis}

Subtheme labels (total $\mathbf{n}=\mathbf{2 3}$ )

Number of studies with data coded into subtheme

\section{Risk compared with other treatments}

( $n=2 \mathrm{HCP}$ studies, 2 patient studies)

Risk compared with other hazards ( $n=3$ HCP studies)

Risk of contracting an illness from contaminated blood

( $n=4$ HCP studies, 6 patient studies)

Adverse reaction to a blood transfusion ( $n=1$ HCP study, 3 patient studies)

Risk of death from blood transfusion ( $n=2$ HCP studies, 1 patient study)

Generalised risk ( $n=7$ HCP studies)
Stage 2 of synthesis Themes $(n=5)$

\section{Safety / Risk}

Generalised concern about blood
transfusion
( $n=3$ HCP studies, 5 patient studies)
transfusion (n=3 HCP studies, 5 patient studies)

Concern about use of alternatives ( $n=3$ HCP studies)

Worry relating to transfusion risk ( $n=2$ patient studies)
Negative emotions 
Patients' and Health Care Professionals' Perceptions of Blood Transfusion: A Systematic Review

'Fifty-four [transfusion] recipients (38\%) were apprehensive about receiving transfusions: 34 were afraid of transfusion per se' $(p .25)^{14}$.

'Because nurses and physicians consider transfusion practice important, the risk is enormous and we are so frightened of harming patients that everyone meditates on the problem' (FG1 Site 5, p.1690) ${ }^{2}$.

$38.2 \%$ of 73 physicians were concerned about medical error adverse events (given wrong blood) (p. 1306) ${ }^{9}$.

'One of the main influences on uptake of PAD [for clinicians, surgeons \& anaesthetists] was described as patient demand. Some [clinicians and surgeons] commented that use of cell-salvage is also restricted because it did not reduce the need for allogeneic blood transfusion' (p.232 \& 234) $)^{12}$.

I am confident [to watch and wait] provided that the patient is stable and in the ICU "Depending on the situation, if the patient is stable it's not hard; if they are unstable it is very difficult." (ICU 2) (p. 5) $)^{15}$.

' $52 \%$ of 77 GPs and $59 \%$ of 79 Anaesthetists would choose a blood substitute over donor blood' (p.185) ${ }^{6}$. $82 \%$ of 38 post-surgical patients preferred to use PAD before surgery, either due to protection from disease $(65 \%)$, peace of mind $(16 \%)$, compatibility $(19 \%)$ or to reduce burden on national blood supply $(26 \%)(p .25)^{5}$.

'Willingness to pay [for autologous transfusion] increases greatly as dread of getting a transfusion of someone else's blood increases' (p.9) ${ }^{16}$.

Patients do better in general: "...there is accumulating data that shows patients do better if you minimize the amount of blood that they get." (ICU 1) (p.6) $)^{15}$.

Some hospice patients $(n=10)$ perceived great benefit from transfusion while others did not "...you know I feel better after, sometimes the next day I feel very lively" ' (P8, p.174) ${ }^{17}$.

Blood transfusion was perceived to be very beneficial (Dimension 3: Benefit = very important benefit vs. little or no benefit [equal to prescription drugs]) $(p .774)^{3}$.

$76 \%$ of 110 patients understood that their transfusion was necessary, either due to blood loss (mostly patients receiving one-off transfusions) or because of low blood count (mostly reported by regular recipients) (p.169) ${ }^{18}$.

'Patients were more likely to disagree or strongly disagree [after transfusion counselling] with the fact that doctors relied too much on transfusion' (p. 297)

Internists, oncologists, geriatricians, family physicians and nurses: 'Indications for transfusion': acute bleeding (89\%), functional deterioration (73\%), and anaemia resulting from chemo- and/or radiotherapy (62\%)' $(p .544)^{20}$.

\author{
Apprehension about receiving a \\ transfusion \\ ( $n=2$ patient studies) \\ Fear of transfusion errors \\ ( $n=2$ HCP studies)
}

Confidence of using alternatives

( $n=2$ HCP studies)

Preference for alternatives to allogeneic transfusion

( $n=3$ HCP studies, 1 patient study)

Dread increases 'willingness to pay' for autologous transfusion

( $n=2$ patient studies)

Advantages / disadvantages of alternatives

( $n=3$ HCP studies)

\author{
Alternatives \\ (e.g. \\ autologous, cell \\ salvage, \\ monitoring)
}

\author{
Some patients perceived benefit, i.e. felt Health benefits \\ better after a transfusion \\ ( $n=2$ patient studies) \\ Benefit compared with other \\ treatments \\ ( $n=1$ HCP study) \\ Necessity of transfusion \\ ( $n=2$ patient studies)

Transfusion counselling changed
$\begin{aligned} & \text { patients' perceptions } \\ & \text { ( } n=1 \text { patient study) }\end{aligned}$ \\ Transfusion prescription clinical \\ indications and contraindications \\ ( $n=2$ HCP studies)
}


Patients' and Health Care Professionals' Perceptions of Blood Transfusion: A Systematic Review

Major influences on reducing need for allogeneic blood transfusion [in clinicians] include 'a "radical change away from considering blood transfusion good for everybody"; tolerance of lower haemoglobin levels ...' $($ p.232)

'Twenty percent of 126 transfusion recipients stated that they would refuse blood transfusion even if they are in need, because of the risk of requiring an infectious disease' (p.677) ${ }^{7}$.

"I do not recall talking about the transfusion or completely understanding about it but all I remember thinking is that it was life and death and I just wanted to get better" (Patient 55; p.169) ${ }^{18}$.
Transfusion prescription: influences

( $n=6 \mathrm{HCP}$ studies)

Patient decision making

( $n=4$ patient studies)

References:

1. Court EL, Robinson JA, Hocken DB. Informed consent and patient understanding of blood transfusion. Transfusion Medicine 2011;21: 183-9.

2. Heddle NM, Fung M, Hervig T, Szczepiorkowski ZM, Torretta L, Arnold E, Lane S, Murphy MF, Collaborative B. Challenges and opportunities to prevent transfusion errors: a Qualitative Evaluation for Safer Transfusion (QUEST). Transfusion 2012;52: 1687-95.

3. Lee DH, Mehta MD, James PD. Differences in the perception of blood transfusion risk between laypeople and physicians. Transfusion 2003;43: 772-8.

4. D'Souza RFC, Glynn MJ, Alstead E, Osonayo C, Foster GR. Knowledge of chronic hepatitis C among East London primary care physicians following the Deparment of Health's educational campaign. QJM - Monthly Journal of the Association of Physicians 2004;97: 3316.

5. Moxey A, O'connell D, Treloar C, Han P, Henry D. Blood transfusion and autologous donation: a survey of post-surgical patients, interest group members and the public. Transfusion Medicine 2005;15: 19-32.

6. Lowe KC, Farrell K, Ferguson EM, James V. Current perceived risks of transfusion in the UK and relevance to the future acceptance of blood substitutes. Artificial cells, blood substitutes, and immobilization biotechnology 2001;29: 179-89.

7. Shah MS, Islam A, Rahman A, Rahman MM, Akter D, Afrin S. To evaluate the extent of awareness about hazards of blood transfusion among the blood recipients. Mymensingh medical journal 2012;21: 674-8.

8. Graham ID, Alvarez G, Tetroe J, McAuley L, Laupacis A. Factors influencing the adoption of blood alternatives to minimize allogeneic transfusion: the perspective of eight Ontario hospitals. Canadian journal of surgery 2002;45: 132-40.

9. Vetter TR, Adhami LF, Porterfield JR, Marques MB. Perceptions about blood transfusion: A survey of surgical patients and their anesthesiologists and surgeons. Anesthesia and Analgesia 2014;118: 1301-8.

10. Amin M, Wilson K, Tinmouth $A$, Hébert P. Does a perception of increased blood safety mean increased blood transfusion? An assessment of the risk compensation theory in Canada. BMC Public Health 2004;4: 20-4.

11. Francis JJ, Stockton C, Eccles MP, Johnston M, Cuthbertson B, Grimshaw J, Hyde C, Tinmouth A, Stanworth SJ. Evidence-based selection of theories for designing behaviour change interventions: Using methods based on theoretical construct domains to understand clinicians' blood transfusion behaviour. British Journal of Health Psychology 2009;14: 625-46.

12. Treloar CJ, Hewitson PJ, Henderson KM, Harris G, Henry D, McGrath KM. Factors influencing the uptake of technologies to minimize perioperative allogeneic blood transfusion: An 
Patients' and Health Care Professionals' Perceptions of Blood Transfusion: A Systematic Review

interview study of national and institutional stakeholders. Internal Medicine Journal 2001;31: 230-6.

13. Fitzgerald M, Hodgkinson B, Thorp D. Blood transfusion from the recipient's perspective. Journal of clinical nursing 1999;8: 593-600.

14. Luby SP, Niazt Q, Siddiquit S, Mujeeb SA, Fisher-Hoch S. Patients' perceptions of blood transfusion risks in Karachi, Pakistan. International Journal of Infectious Diseases 2001;5: 246.

15. Islam R, Tinmouth AT, Francis JJ, Brehaut JC, Born J, Stockton C, Stanworth S, Eccles MP, Cuthbertson B, Hyde C, Grimshaw JM. A cross-country comparison of intensive care physicians' beliefs about their transfusion behaviour: a qualitative study using the Theoretical Domains Framework. Implementation science 2012;7: 93.

16. Lee SJ, Neumann PJ, Churchill WH, Cannon ME, Weinstein MC, Johannesson M. Patients' willingness to pay for autologous blood donation. Health policy 1997;40: 1-12.

17. Orme J, Still D, Day R, Evans J, Perkins P. The experiences of patients undergoing blood transfusion in a day hospice. International journal of palliative nursing 2013;19: 171-6.

18. Davis R, Vincent C, Sud A, Noel S, Moss R, Asgheddi M, Abdur-Rahman I, Murphy M. Consent to transfusion: patients' and healthcare professionals' attitudes towards the provision of blood transfusion information. Transfusion Medicine 2012;22: 167-72.

19. Khan MH, Watson HG, Dombrowski SU. Perceived hazards of transfusion: can a clinician tool help patients' understanding? Transfusion Medicine 2012;22: 294-7.

20. Leibovitz A, Baumoehl Y, Walach N, Kaplun V, Sigler E, Balan S, Habot B. Medical staff attitudes: views and positions regarding blood transfusion to terminally ill cancer patients. American Journal of Clinical Oncology 2004;27: 542-6. 
Patients' and Health Care Professionals' Perceptions of Blood Transfusion: A Systematic Review

Appendix D Examples of intersection between themes

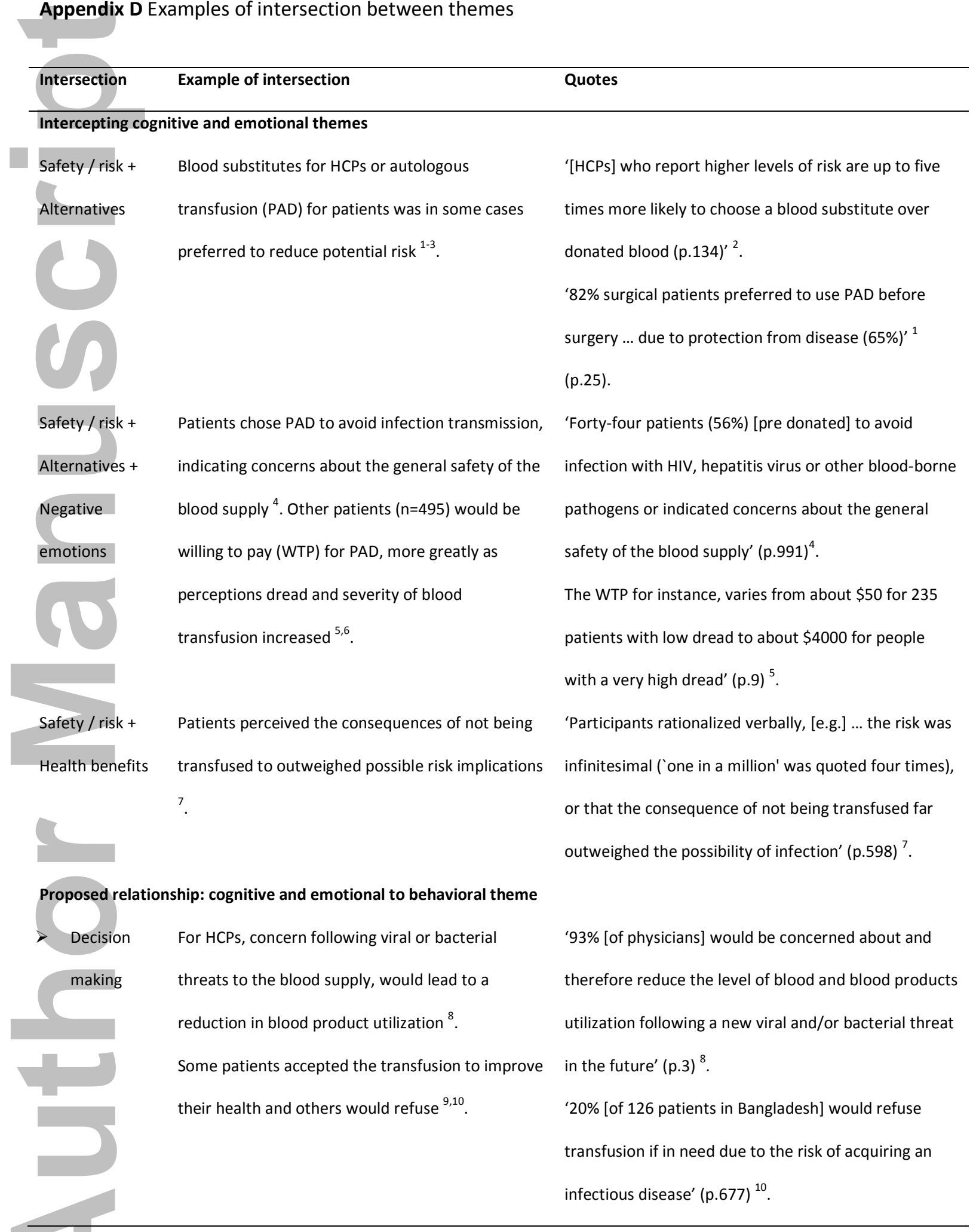

ScholarOne, 375 Greenbrier Drive, Charlottesville, VA, 229011 (434) 964-4100

This article is protected by copyright. All rights reserved. 
Patients' and Health Care Professionals' Perceptions of Blood Transfusion: A Systematic Review

1. Moxey A, O'connell D, Treloar C, Han P, Henry D. Blood transfusion and autologous donation: a survey of post-surgical patients, interest group members and the public. Transfusion Medicine 2005;15: 19-32.

2. Ferguson E, Farrell K, Lowe KC, James V. Perception of risk of blood transfusion: Knowledge, group membership and perceived control. Transfusion Medicine 2001;11: 129-35.

3. Lowe KC, Farrell K, Ferguson EM, James V. Current perceived risks of transfusion in the UK and relevance to the future acceptance of blood substitutes. Artificial cells, blood substitutes, and immobilization biotechnology 2001;29: 179-89.

4. Graham ID, Fergusson D, Dokainish H, Biggs J, McAuley L, Laupacis A. Autologous versus allogeneic transfusion: patients' perceptions and experiences. Canadian Medical Association journal 1999;160: 989-95.

5. Lee SJ, Neumann PJ, Churchill WH, Cannon ME, Weinstein MC, Johannesson M. Patients' willingness to pay for autologous blood donation. Health policy 1997;40: 1-12.

6. Lee SJ, Liljas B, Neumann PJ, Weinstein MC, Johannesson M. The impact of risk information on patients' willingness to pay for autologous blood donation. Medical care 1998;36: 116273.

7. Fitzgerald $M$, Hodgkinson $B$, Thorp D. Blood transfusion from the recipient's perspective. Journal of clinical nursing 1999;8: 593-600.

8. Amin M, Wilson K, Tinmouth A, Hébert P. Does a perception of increased blood safety mean increased blood transfusion? An assessment of the risk compensation theory in Canada. BMC Public Health 2004;4: 20-4.

9. Davis R, Vincent C, Sud A, Noel S, Moss R, Asgheddi M, Abdur-Rahman I, Murphy M. Consent to transfusion: patients' and healthcare professionals' attitudes towards the provision of blood transfusion information. Transfusion Medicine 2012;22: 167-72.

10. Shah MS, Islam A, Rahman A, Rahman MM, Akter D, Afrin S. To evaluate the extent of awareness about hazards of blood transfusion among the blood recipients. Mymensingh medical journal 2012;21: 674-8. 


\section{University Library}

\section{- M M N E R VA A gateway to Melbourne's research publications}

Minerva Access is the Institutional Repository of The University of Melbourne

Author/s:

Abdul-Aziz, B;Lorencatto, F;Stanworth, SJ;Francis, JJ

Title:

Patients' and health care professionals' perceptions of blood transfusion: a systematic review

Date:

2018-02-01

Citation:

Abdul-Aziz, B., Lorencatto, F., Stanworth, S. J. \& Francis, J. J. (2018). Patients' and health care professionals' perceptions of blood transfusion: a systematic review. TRANSFUSION, 58 (2), pp.446-455. https://doi.org/10.1111/trf.14404.

Persistent Link:

http://hdl.handle.net/11343/261096 